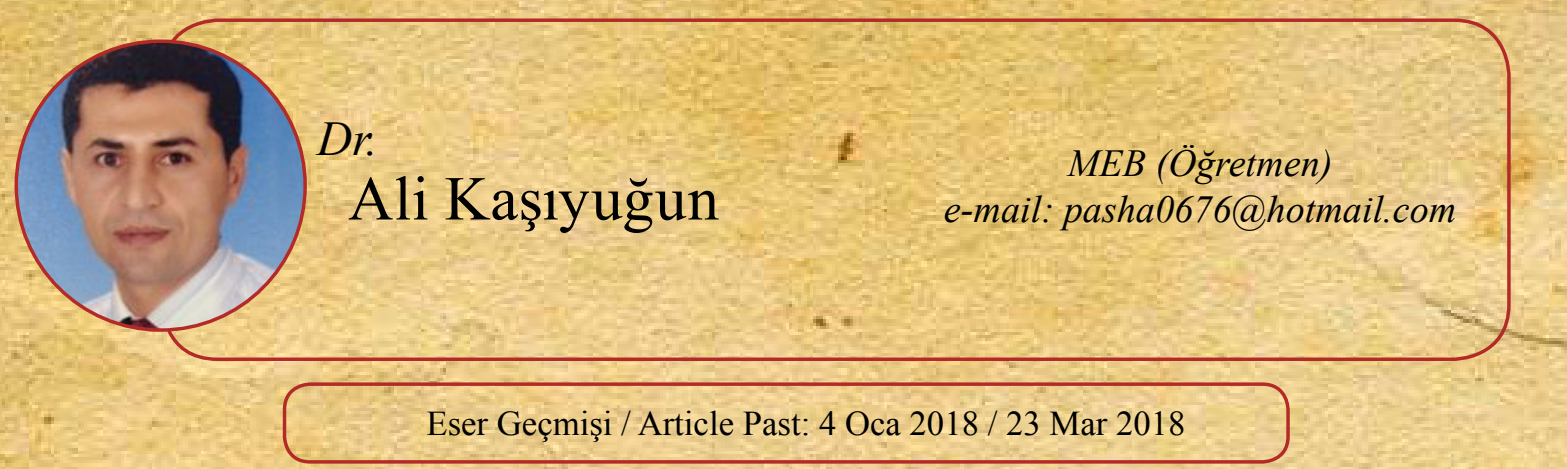

Araştırma Makalesi DOI: $10.21551 / \mathrm{jhf} .375108$

Research Paper Orjinal Makale / Orginal Paper

\title{
I. Dünya Savaşı'nda Esirler Meselesi Üzerine Bazı Değerlendirmeler
}

\author{
Some Thoughts on the Issues of Prisoners in the First World War
}

\section{ÖZET}

I.Dünya Savaşı hakkında birçok çalışma yapılmıştır. Bu çalışmalarda farklı konular işlenmiştir. Bu konulardan birisi de savaş sırasında hasım grubun eline geçen esirlerdir. Esirlerle ilgili gerek ulusal gerekse uluslar arası düzeyde hukuki düzenlemeler yapılmış ancak bu düzenlemelere pek riayet edilmediği görülmektedir. Bu çalışmada I.Dünya Savaşı genelinde esirlere nasıl muameleler yapıldığı, kişi hak ve hürriyetlerinin ne kadar uygulanmaya çalışıldığı sorularına cevap verilmeye çalışılmış ve esirler meselesi üzerinde, arşiv belgeleri ve diğer yayınlar ışığında bazı değerlendirmeler yapılmıştır.

Anahtar kelimler: Osmanlı Devleti, İngiltere, Rusya, Esirler, Esir kampları

\section{ABSTRACT}

There have been lots of studies about World War I. In these studies, various issues have been examined. One of the issues is regarding the prisoners captured by the other party (enemies group) during the war. Legal arrangements have been made regarding (related to, considering) the prisoners both in domestic and in international level, however; these arrangements are not abided.

In this study, generally in the I. World War, it was tried to answer questions about how the prisoners were treated, how much rights and freedoms were tried to be applied, some evaluations were made on the issue of prisoners, in the light of archive documents and the other publications.

Key words: Ottoman State, England, Russia, Prisoners, Prison camps 


\section{Giriş}

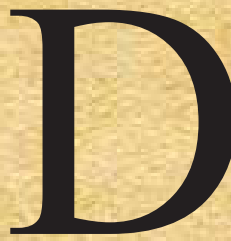

evletler tarih boyunca çeşitli nedenlerden hep karşı karşıya gelmiş ve bunun neticesinde binlerce insan hayatını kaybetmiştir. Ancak hayatını kaybedenlerin dişında hasım gruba tutsak düşen askerler de var olmuştur. Genelde esir veya harp esiri olarak nitelendirilen bu askerler zaman zaman insanlık dışı muamelelere maruz kalmışlardır.

Arapça esr (isare) kökünden türeyen, savaş tutsağ anlamında kullanılan ${ }^{1}$ ve çoğulu üsera olan esir kelimesi dilimize Arapça' dan girmiş bir kelime olup "savaşta düşman eline geçen kimse, kul, köle, cariye, birinin veya bir durumun hükmü ve buyruğu altına girmiş". anlamında kullanılan bir kelime iken, seby kelimesi ise daha çok kadın ve çocuk tutsaklar için kullanılan bir tabir olmuştur³.

Zaman içerisinde savaş koşullarının ve şekillerinin değişimi ile birlikte esirlere yapılan muamelelerde de değişiklikler olmaya başlamış ve birtakım hukuki düzenlemeler yapılmıştır. Bunlardan birisi 1906 tarihli Cenevre Sözleşmesi, bir diğeri 1907 tarihli Lahey Sözleşmesi'dir. Cenevre Sözleşmesi'nde esirlerle ilgili alınan kararlarda özetle hasta ve yaralı esirlere milliyet ayrımı yapılmaksızın tedavi edilmeleri, yaralıların her türlü kötü muameleden korunması, yardım cemiyetlerine engel olunmaması gibi hususlara yer verilmektedir. Uluslararası arenada bu gelişmeler yaşanırken Osmanlı Devleti de olası bir savaş durumunda kendi topraklarında bulunan esirlere nasıl muamele edeceğine dair çalışmalar yapmıştır. Bu doğrultuda esirlere yapılacak muameleye ilişkin olarak "Üsera Hakkında Talimatname" ilan edilmiştir. 5 bölüm ve 28 maddeden oluşan talimatnamenin birinci bölümünde; esirlerin kamplara nasıl ve ne şekilde sevk edileceği, ikinci bölümde esirlere hangi konularda ne kadar müsaade edileceği ve müsamaha tanınacağı, üçüncü bölümde ödeme ve iaşe konuları üzerinde durulurken dördüncü bölümde esir komisyonları ve işleyişi hakkında izahatlar yer almakta son bölümde ise cezayı gerektiren hallerde nasıl bir yol izleneceği hakkında bilgiler verilmiştir ${ }^{4}$. Ancak tüm bu gelişmelere rağmen I.Dünya Savaşı, insan hakları ihlalleri açısından birçok olumsuzluğa neden olacaktır.

Osmanlı Devleti, daha savaşın başlarından itibaren esirlerle ilgili çalışmalara başlayacaktır. Esirlere ait işlemlerin düzenli ve sorunsuz yürütülebilmesi için 15 Nisan $1915^{\prime}$ te üst rütbeli subayların yönetiminde üsera komisyonları kurulacaktır. Savaşan ülkelerde bulunan üsera komisyonları, her esire ait isim, künye ve esirlerin tutulduğu yere ait bilgileri listeler halinde tutacaktı. Savaşın ilerleyen yıllarında alınan esir sayısında artış olunca üsera şubeleri kurulmuştur. Üsera komisyonlarının sayısı arttıkça, koordinasyon

1 Cemil Kutlu, I.Dünya Savaşı'’nda Rusya'daki Türk Savaş Esirleri ve Bunların Yurda Döndürülme Faaliyetleri, Atatürk Üniversitesi Atatürk İlkeleri ve İnkılâp Tarihi Enstitüsü (Yayınlanmamış Doktora Tezi), Erzurum 1997, s.XXII

2 Mücahit Özçelik, Birinci Dünya Savaşı'nda Türkiye'deki Yabancı Esirler, Gazi Üniversitesi Sosyal Bilimler Enstitüsü (Yayınlanmamış Doktora Tezi), Ankara 2010, s.1

3 Nebahat Oran Arslan, I.Dünya Savaşı'nda Türkiye'deki Rus Savaş Esirleri ve Bunların İadeleri, Atatürk Üniversitesi Sosyal Bilimler Enstitüsü (Yayınlanmamış Doktora Tezi), Erzurum 2003, s. 14

4 Özçelik, a.g.t., s.27-28; Mahmut Akkor, I. Dünya Savaşı'nda Anadolu'daki İngiliz Esirleri ve Esir Kampları, Sakarya Üniversitesi Sosyal Bilimler Enstitüsü (Yayınlanmamış Doktora Tezi), Sakarya 2013, s.55-58; Arslan, a.g.t, s.24-28. Lahey ve Cenevre Sözleşmeleri hakkında ayrıntılı bilgi için bak. Kutlu, a.g.t., s.XXVI-XXXII 
eksikliği ve bilgi karmaşasının da yaşanması söz konusu olacağından esirlere ait işlemlerin tek elden ve daha düzenli yapılabilmesi için 3 Nisan 1916'da Menzil Müfettiş-i Umumiliği kurularak esirlerle ilgili tüm düzenlemeler buradán sevk ve idare edilmeye başlanmıştır

Savaş sırasında askerler esir edilmekteydi. Ancak bazen siviller de esir alınmıştır. Savaş sırasında zaman zaman savunmasız veya savaş alanı dişında olan yerler bombalanmış ve savaş kurallarına uygun hareket edilmemiştir. Osmanlı Devleti, sivil yerleşim merkezlerine yapılan saldırıların durdurulması için İtilaf devletlerine defalarca protestoda bulunmuş ancak olumlu bir cevap alamayınca bazı tedbirler alma yoluna gitmiştir. Misilleme veya karşıllklı zarar verdirme olarak nitelenen bu uygulamalar; İngiliz, Rus veya Fransız uyruklu olup üst düzey görevlerde bulunan itibarlı kişilerin tutuklanarak ülkenin iç kısımlarına gönderilmesi, İtilaf devletlerinin Osmanlı topraklarındaki mallarına el konularak kişisel zarar ziyanların tazmin edilmesi ve şehit edilen, yaralanan veya esir edilen kişi sayıısı kadar İtilaf devletleri vatandaşlarının bulundukları yerlerden başka yerlere sürgün edilmesi şeklinde özetlenebilir ${ }^{6}$. Örneğin Fransız kumandası altında bulunan Meis Adası Rumlarından bir çetenin Teke livasına bağlı Kale Köyü'ne saldırarak 6 erkek ve 1 kadını yanlarında götürmeleri üzerine misilleme olarak İstanbul'da yaşayan 6 erkek ve 1 kadın 23 Mayıs 1916 tarihinde Polis Müdüriyet-i Umumiyesi tarafından Çorum'a sürgün edilmiştir?.

\section{Türk Esirleri’nin Kamplara Taşınması}

Esirler, daha kalacakları kamplara ulaşmadan, esaret hayatında ne gibi zorluklarla karşılaşabileceklerinin ilk belirtilerini kamplara nakledilirlerken yaşamaya başlamışlardır. $\mathrm{Bu}$ zorlukları en çok Rusya'da kalan esirler yaşamıştır. Bu zorluğun temelinde yatan faktör soğuk kış şartlarıdır. Osmanlı Devleti'nin en çok esir verdiği ülke ise İngiltere olmuştur. Ortalama 135.000 kişi civarında asker ve sivil esaret hayatr yaşamak zorunda kalmıştır. Bu kadar insanı tek bir merkezde barındırmak mümkün değildir. Ayrıca siyasi sebeplerden dolayı da bu esirler Hindistan, Mısır, Kıbrıs, Malta, Hindiçini gibi farklı yerlere gönderilmiştir. Türk esirlerini ilk olarak Bağdat ve Basra' daki toplama kamplarına götüren İngilizler buradan da çeşitli yerlere trenle, gemiyle ya da yaya olarak göndermişlerdir. Kafkasya, Romanya ve Galiçya cephelerinde savaşan Osmanlı askerlerini esir alan Ruslar ise ilk etapta Sarıkamış ve Kars'ta esirleri toplamış ve oradan Rusya'ya sevk etmişlerdir. Toplama kamplarında Osmanlıca bilen bir Rus subayı tarafından sorguya çekilerek adları, lakapları, sınıfları, meslek veya ihtisasları üsera defterine kaydedilip sağlık kontrolleri yapıldıktan sonra esirler, "tekluşki" adı verilen vagonlara bindirilerek Azerbaycan'a ve oradan Hazar Denizi'ndeki Nargin adasına sevk edilmiştir. Türk esirlerle birlikte Alman, Avusturyalı ve Bulgarların da tutulduğu ve en büyük toplanma merkezi olan adada esirlerin hangi bölgede, hangi kampta kalacağı kararlaştırıldıktan sonra Sibirya, Kazan gibi bölgelere gönderilmişlerdir. Ancak esirler, yaşam koşullarının çok kötü olduğu bu adaya gelene

5 Özçelik, a.g.t, s.29-33; Akkor, ...Ingiliz Esirleri ve Esir Kamplart, s.59-61; Arslan, a.g.t, s.30-36

6 Mehmet Temel, "Birinci Dünya Savaşı Yıllarında 1907 Tarihli Lahey Sözleşmelerine Aykırı Davranan İtilaf Devletlerine Karşı Osmanlı Devleti’nin Aldığı Bazı Önlemler”, Balıkesir Üniversitesi Sosyal Bilimler Enstitüsü Dergisi, C.6, S.10, Balıkesir 2003, s.149-150

7 Ramazan Sonat, "I.Dünya Savaşı Yıllarında Osmanlı Devletinin Muhasım Devlet Tebaası Politikası (19141918)", Tarihin Peşinde Dergisi, Y11, 2014, S.11, s.263

8 Cemil Kutlu, tezinde Türk esirlerin bindirildiği vagonlara "Eploşka" denildiğini belirtmektedir. Kutlu, a.g.t, s.4649. 
kadar da kötü muamelelere maruz kalmışlardır. Taşınırken kimi zaman üstleri soyulan esirler, Ermenilerin yoğunlukta olduğu yerlerden geçerken hakaretlere ve saldırılara da maruz kalmışlardır9. Türk esirlerin özellikle Sibirya'ya gönderilmesinin nedeni Türk ve Müslümanların yoğun olarak yaşadıkları yerlerden uzak tutulmaya çalışılmasıdır. $\mathrm{Bu}$ nedenle Orta Asya yerine Sibirya tercih edilmiștir ${ }^{10}$.

Türk esirler kamplara gönderilirken çok büyük sıkıntılarla karşı karşıya kalmışlardır. Örneğin 12 Ocak 1915 tarihli "Penza Haberleri” gazetesinde yer alan bir haberde; Türkler arasında çokça ihtiyar olduğu ve diğer esirlerden ayrı taşındıkları, bekçilerin korudukları vagonlardan çıkmalarına izin verilmediği, oysa Avusturyalı esirlerin rahatlıkla su, ekmek almaya gittikleri yazılmaktadır. 1916 tarihli "Pester Lloyd" adlı bir başka gazetede ise Penza'ya getirilen 700 Türk esirin vagonlarda kapalı tutulması sebebiyle tümünün öldüğü bilgisine yer verilmektedir ${ }^{11}$. Frankfurt Çaytong Gazetesi'nde yer alan bir haberde (22.6.1916) Şubat 1916 'da Krasnobarsk'tan Primor'a sevk edilen 1.000 Osmanlı esirinden sadece 200'ünün Primor'a varabildiği belirtilmektedir. Sarıkamış’ta esir edilen Türk askerlerinin durumunu İsveç Salib-i Ahmer Murahhası Graf Londrof ş̧öyle tarif etmektedir; «İzdihamdan, kokudan yanlarına varılmayan, kapıları kilitli ve içerisi tıka basa Osmanlı esirleri ile dolu büyük bir tren 1915 Ocak ayının sonunda Sirzan istasyonuna geldi. İçindeki esirler, insan kılığından çıkmıs, açlıktan renkleri sararmış, yanakları çökük, elmacık kemikleri dişarı firlamış, kımıldayamayacak şekilde yorgun ve kuvvetten düşmüş, elbisesiz, ayakları çıplak, kâinatta mevcut bütün bulaşıcı hastalıklarla müptela bir haldeydi. Bu feci manzara insanların yüzlerini kızartacak ve kalplerini sızlatacak derecedeydi." Bir başka olay ise 1916 Ocak ayında Hasankale'den alınan 13 subay ve 350 askerle yola çıkarılan bir esir kafilesinde, yolda yürümekte zorlanan 95 askerin kafilenin gözleri önünde kurşuna dizilmesidir. Gece üstü açık dört duvar arasında bir yere tıkılan kafilede 8 asker donarak şehit olmuştur ${ }^{12}$. Bu tarz haber ve olaylar Türk esirlerin yolculukları sırasında yaşadıkları sıkıntıları açıkça gözler önüne sermektedir.

Osmanlı Devleti'nde ise esirler kamplara götürülmeden önce geçici kamplarda tutulmuş daha sonra gidecekleri kamplara gönderilmişlerdir. Örneğin Rus subay esirleri için Trabzon'da bir otel tahsis edilmiş, Erzurum'da aynı şekilde subaylar Pastırmacı Hanı'nda tutulurken erler jandarma kışlasında veya kale koğuşlarında tutulmuşlardır. Hasta olanlar ise hastanelere gönderilmişlerdir ${ }^{13}$. Esirler kamplara nakledilirken gerek demiryollarının eksikliği gerekse deniz ulaşımının yetersizliği sebebiyle daha çok kara yoluyla hayvanlar

9 Mahmut Akkor, I. Dünya Savaşında Çeşitli Ülkelerdeki Türk Esir Kampları, Sakarya Üniversitesi Sosyal Bilimler Enstitüsü (Yayınlanmamış Yüksek Lisans Tezi), Sakarya 2006, s.40-42.

10 Ali Asker, "Birinci Dünya Savaşı'nda Rusya'daki Türk Esirleri Konusunda Bazı Tespitler", 1914'ten 2014'e 100'üncü Yilında Birinci Dünya Savaşı'nı Anlamak Uluslararası Sempozyumu, 20-21 Kasım 2014, İstanbul, s.557

11 Asker, a,g,m, s.558-559; Osmanlı Belgelerinde Birinci Dünya Harbi C.1, Başbakanlık Devlet Arşivleri Genel Müdürlügüi Osmanlı Arşivi Daire Başkanlığı Yayınları, Yayın Nu: 130, İstanbul 2013, s.322-323

12 Zafer SSen, "I.Dünya Savaşında Osmanlı Esirleri ve Dramları", http://www.zafersen.com/birinci-dunya-savasindaosmanli-esirleri-ve-dramlari.pdf (Erişim tarihi 04.01.2018)

13 Arslan, a.g.t, s.63. Türkiye'de ilk kurulan esir kampları İzmit, Erzincan ve Şam üsera garnizonlarıdır. Daha sonra esir sayısının artmasıyla beraber esir kamplarının da sayısı artmıştır. Afyonkarahisar, Ankara, Sivas, Manisa, Musul, Adana, Bursa, Eskişehir, Kastamonu, Yozgat, Konya gibi yerlerde kamplar açılmıştır. Bak. Arslan, a.g.t., s.65-67 
tarafından çekilen araçlarla nakledilmişlerdir ${ }^{14}$.

Rusya'da bulunan Türk esirler için çeşitli bốlgelerde yardım komiteleri kurulmuştur. Bu komiteler bulundukları bölgelerdeki esirlere, gerek maddi gerekse manevi yardımlarda bulunmuşlardır. Konuyla ilgili olarak Akçura; "Rusya'da sakin Müslümanlar, yani Şimal Türkleri, Osmanlı üserasına her türlü ve birçok muavenette bulunmuşlardir. Daha Çar idaresi devam ederken bile bazı mahallerde üseraya muavenet komiteleri teşkil ederek yakınlarındaki karargâhlara bilhassa erzak vermek suretiyle muavenet ettikleri gibi, teşebbüs-i zatileriyle karargâhlardan çıkıp memleketlerine avdet eden müteşebbis ve cesur esirlerimize her türlü teshilatı ihzar etmişler ve nakdi ve fikri muavenetlerini esirgememişlerdir ve bu yolda muavenetlerinden dolayı bazı Müslümanlar, Çar hükümeti tarafindan mücazata bile duçar olmuşlardır" diyerek on altı yardım komitesinin isimlerini vermektedir ${ }^{15}$.

Benzer yardım cemiyetleri Azerbaycan'da da kurulmuştur. Bu cemiyetler yiyecek, giyecek ve yakacak yardımıyla esirlerin içinde bulundukları zor koşulları hafifletmeye çalışmışlardır ${ }^{16}$.

\section{Esir Sayıları}

I.Dünya Savaşı sırasında esir düşen askerlerin sayısını tespit etmek oldukça zor görünmektedir. Çünkü kayıtlar düzenli bir şekilde tutulamamıştır. Yalnızca Rusya örneğine bakıldığında meselenin ehemmiyeti açıkça anlaşılmaktadır. Örneğin Rusya'da bulunan esirlerin kayıtları üç farklı kurum tarafından tutulmuştur. Bunlar; Mülteci ve Göçmen Komisyonu'na bağlı Merkezi Bilgi Bürosu, Genelkurmay Başkanlığı Sekretaryası ve Moskova Askeri Dairesi Karargâhı. Bu kurumların sundukları verilerin oldukça çelişkili olduğu görülmektedir. Rusya'da bulunan esir sayısi Rusya Kızılhaç Cemiyeti'nin verilerine göre 1.782.966, Genelkurmay verilerine göre 1.961.333, Merkezi Bilgi Bürosunun verilerine göre ise $2.328 .540^{\prime} \operatorname{tır}^{17}$. Görüldüğ̈̈ gibi her kurum esir sayısını farklı vermektedir. Dolayısıyla net bir rakam vermenin zorluğu kendiliğinden ortaya çıkmaktadır.

Osmanlı Devleti, Amiral Souchon komutasındaki donanmanın 29 Ekim 1914'te Rus limanlarını topa tutması üzerine 2 Kasım 1914'te I.Dünya Savaşı'na resmen dâhil olmuş, 13 Kasım 1914 'te cihad ${ }^{18}$ ilan ederek on kadar cephede savaşmak durumunda kalmıştır. Yaklaşık 2.850.000 civarında bir asker silâhaltına alınmış ancak savaş süresince bunlardan ne kadarının esir düştüğü net olarak ortaya konulamamıştır. Zira savaş koşullarında bu sayıyı net olarak ortaya koymak mümkün değildir. Mesela savaşın sonlarına doğru Rusya'daki Türk esirlerinin durumlarını incelemek, onlara bazı ayni ve nakdi yardımlar ulaştırmak için görevlendirilen Yusuf Akçura, faaliyetleriyle ilgili hazırladığı raporunda

14 Arslan, a.g.t, s.50

15 Yusuf Akçura, Rusya Üsera Murahhassı Yusuf Akçura Bey’in Raporu, Matbaa-i Orhaniye, Dersaadet 1335, s.28-29

16 Akkor, ...Türk Esir Kampları, s.136-137

17 Asker, $a, g, m$, s.554 ve 32 numaralı dipnot bilgisi

18 BOA, İ.MBH, D:16, G:106 (Kaynakça kısmında arşiv belgelerinin tam künyeleri verilecektir.); İkdam, "Cihad-1 Ekber", 13 Kasım 1914, Numru: 6369, s.1; Sabah, "Beyanname-i Hümayun Suretidir", 13 Kasım 1914, Numru: 9036, s.1; Tanin, “Beyanname-i Hümayun Suretidir”, 13 Teşrin-i sani 1914, Numru: 2117 , s.1 
Rusya'da bulunan esirlerle ilgili net bir rakam verememekte, “... tahminen 60-70 bin Osmanlının Rusya'da esir bulunduğunu nazar-ı dikkate alan Hilal-i Ahmer Cemiyeti..." şeklinde bir ifade kullanarak net bir sayı vermekten kaçınmaktadır ${ }^{19}$. Zaman içerisinde bu esirlerden 20-25 bin kadarı farklı yollarla Türkiye'ye dönebilmiş geri kalan Türk savaş esirlerinin büyük bir kısmı maalesef Rusya'da hayatlarını kaybetmiștir ${ }^{20}$. Ancak 358.000 civarında esir ve kayıp olduğu, bunlardan ne kadarının esir olduğu veya firar ettiği tam olarak bilinmemekle beraber 200.000 civarında esir verildiği buna mukabil yaklaşık 25.000 esir alındığı tahmin edilmektedir ${ }^{21}$. Aslında farklı çalışmalarda farklı rakamlar kullanılmaktadır. Bu çalışmaların birisinde yalnız 1916 yılında Osmanlı Devleti'nde bulunan esir miktarı $26.596^{22}$ olarak verilmekte iken bir başka çalışmada Mondros Ateşkes Antlaşması'ndan 14 Şubat 1921 tarihine kadar Türkiye'ye iade edilen esir sayısı 634 subay, 18.926 er olarak kaydedilmektedir. Bunlardan başka iade edilmeyen 540 subay, 2.500 er ve 250 sivil esir bulunduğu ifade edilerek Ruslara esir düşen Türk esir sayısı 22.850 kişi olarak verilmektedir ${ }^{23}$. Fakat burada geride kalan esir sayıları belirtilmemektedir. Bir diğer çalışmada ise Osmanlı Devleti'nin esir düşen asker miktarı şu şekilde verilmektedir. İngiltere:113.583, Rusya:20.595, Fransa:804, İtalya:100 olmak üzere toplam $133.839^{24}$. Bir diğer çalışmada İngilizlerin aldıkları esir sayısı 135.000 olarak verilmekte iken alınan esir sayıs1 23.500 olarak ifade edilmektedir ${ }^{25}$.

I. Dünya Savaşı'nda Osmanlı Devleti'nin en çok esir verdiği ülke İngiltere olmakla birlikte, burada da ne kadar esir olduğunu tam olarak bilinmemektedir. Arşivler ve eldeki kaynakların taranması sonucu ulaşılan bilgiler de net bir rakam verme noktasında yetersiz kalmaktadır. Atase arşivinden çıkan bir belgeye göre toplam esir sayısı 133.839 olarak belirtilmektedir. Ancak bu belgeyi hazırlayan kişi de bu miktardan tatmin olamamış olacak ki belgenin sol üst köşesine düşmüş olduğu notta "Bu cetvel hatalıdır, Hilal-i Ahmer'den tahsis $^{26}$ edilmesi lazımdır" ibaresini düşmüştür ${ }^{27}$.

İngiliz esirlerinin miktarına ilişkin ilk bilgi 14 Kasım 1915 tarihine aittir. Bu tarihte İngiliz esirlerinin sayısı 535 olarak ifade edilmektedir. Savaşın son günlerde düzenlenen bir

19 Akçura, ...Rapor, s.3

20 Nuri Köstüklü, "I. Dünya Savaşında Rusya’nın Ukrayna ve Diğer Bölgelerindeki Türk Savaş Esirlerine Dair Bazı Tespitler", Atatürk Araşturma Merkezi Dergisi C.XXVIII, S.83, Ankara, Temmuz 2012, s.4

21 Akkor, ...Türk Esir Kampları, s.39; Özçelik, a.g.t, s.32. Özçelik, çalışmasının bir diğer yerinde savaşın başından sonuna kadar alınan esir sayısını şöyle vermektedir. 5.375 civarında Rus, 8.326 civarında Hint, 9.976 civarında İngiliz, 2.000 civarında Romen, 120 civarında Fransız esir olmak üzere itilaf devletlerinden toplam 26 bin civarında esir almıştır. Bilgi için bak. Özçelik, a.g.t, s.207. Nebahat Oran Arslan ise tezinde 1914-1917 yılları arasında ele geçirilen Rus esir sayısının 10.000 ile 15.000 arasında olduğunun tahmin edildiğini belirtmektedir. Bilgi için bak. Arslan, a.g.t, s.38-39.

22 Mesut Çapa, "Birinci Dünya Savaşında Türkiye'de İtilaf Devletleri Askerleri”, Toplumsal Tarih Dergisi, Haziran 1999, s.54

23 Vasif Gafarov, "Birinci Dünya Savaşı Yıllarında Rus Esirlerin Tutuldukları Osmanlı Kampları Ve Yozgat Üsera Garnizonu"'I.Uluslararası Bozok Sempozyumu Bildiri Kitabı C.2, s.125

24 Celal Metin, "Yusuf Akçura ve I.Dünya Savaşı'nda Rusya'daki Türk Esirleri", Modern Türklük Araştırmaları Dergisi, C.2, S.3, Ankara 2005, s.39 (Dipnot no:13). Ayrica bak.Mustafa Arikan, "Birinci Cihan Harbi Türk Esir Mektuplarında Duygu ve Düşünceler", Osmanlı Araştırmaları Dergisi XI, İstanbul 1991, s.35.

25 Mahmut Akkor, "I.Dünya Savaşı'nda Kocaeli'de İngiliz Esirleri”, Uluslar arası Gazi Akça Koca ve Kocaeli Tarihi Sempozyumu, 2-4 May1s 2014, s.853-854

26* Cümle aynen alındığı için "tahsis" şeklinde yazıldı ancak cümlenin akışına göre doğrusu "tashih" olmalıdır.

27 Akkor, ...Türk Esir Kampları, s.39. 
belge, İngiliz esirlerinin sayısına dair çok net bir bilgi vermektedir. İngiliz arşiv belgelerinde tespit edilen bu rakam, 16.583 'tür. Rapor olarak düzenlenen bir belgeden çıkan bu bilginin kayda geçtiği tarih, 25 Ekim 1918'dir. Bu tarih ayĥ́ zamanda Osmanlı Devleti'nin savaştan çekildiği günlere denk gelmesi açısından da değerlendirildiğinde esir sayısının gerçeğe yakın olması muhtemeldir. Kut'ül-Amâre savaşında Osmanlı Devleti'nin Ingiltere'den aldığı esir miktarı, Atase arşivindeki belgelerde ortalama 13.000 kişi civarındadır. Buna mukabil, İngiliz kaynaklarında bu savaşa dair esir miktarı, 13.672 olarak kayıt altına alınmış̧ır. Çanakkale cephesindeki duruma bakılacak olunursa, The Times gazetesinde çıkan bir köşe yazısına göre İngilizlerin, ölen İngiliz askerleri haricindeki kaybı, 8.394 olarak ifade edilmiştir. Osmanlı Devleti'nin Süveyş Kanalı'na saldırısıyla başlayıp İngiliz ileri harekâtı ile devam eden cephede Osmanlı Devleti tarafından alınan esir miktarları; Katya bölgesinde yaklaşık 500 kişi, I. Gazze,Muharebelerinde yaklaşık 400 kişi, Kudüs'ün kuzeyinde Tellifül bölgesinde yapılan çatışmalarda, 300'den fazla olmak üzere toplam 1.200 'den fazla İngiliz askeri esir alınmıştır. Osmanlı Devleti ile İngiltere'nin mücadele ettiği son cephe olan Hicaz-Asir-Yemen Cephesi'nde ise İngiliz esir miktarına dair bir kayıt bulunamamıştır. Her bir cephe için elde edilen rakamlar toplandığında ortaya çıkan İngiliz esirlerinin sayısı, 23.500 civarında olduğu anlaşılmaktadır ${ }^{28}$.

Anadolu'da bulunan esir miktarı hakkında da tam bir bilgiye sahip değiliz, gerek o-dönemin koşulları içinde esir sayılarının üzerinde yeteri kadar durulamaması gerekse muhtelif belgelerin bu iş için tasnif edilmemesi bu eksikliğin karşısındaki en büyük engel olarak karşımıza çıkmaktadır. Yine de tahmini bir rakam verilecek olursa, Osmanlı Devleti'nin elinde 15.702 İngiliz, 4.935 Rus, 700 İtalyan ve 169 Fransız askeri olmak üzere toplam 21.506 İtilaf devletleri esiri bulunmaktadır. 30 Ekim 1918 tarihinde mütarekenin imzalandığı gün itibariyle ölen esirler hesaptan çıkarıldığında yaklaşık 13.500 esir, Osmanlı Devleti'nin sınırları içindeki muhtelif kamplarda bulunmaktadır ${ }^{29}$.

\section{Esirlere Yapılan Muameleler}

Esirler, devletin uygun gördüğü şekilde çeşitli kamplara yerleştirilmiş olsa da kimi zaman bulundukları kamplardan hastalık ve benzeri gerekçelerle hoşnut olmayıp kendi istekleriyle yer değişikliği talebinde bulunanlar olmuştur. Ancak bu taleplerin yerine getirilmesi sadece Başkomutanlıktan gelen emirler doğrultusunda mümkün olup içinde bulunulan şartlara göre değerlendirme yapılmıştır. Genellikle doktor raporu getirmeleri karşılığında yer değişikliği konusunda gerekli kolaylıklar gösterilmiş ve talepler olumlu karşılanmıştır. Aykırı bir durum olmadıkça, esirlerin talepleri dikkate alınarak kamp değişiklikleri yapılmıştır. Esirlerin kamp değişikliği talebi, aktarılmak istenen bölgenin yerleşim durumuyla dayakından ilgilidir.Zira herbölgede garnizon sistemi bulunmamaktadır. Bunun yerine ev ve otel kiralama uygulamasına gidilmiştir. Kiralama yöntemiyle esir iskânında, subayların konaklama ücreti, Osmanlı Devleti tarafından karşılanmıştır. Hatta ilk başlarda kendi cebinden konaklama ücreti ödeyenlerin paraları daha sonra iade edilmiştir ${ }^{30}$. Tabir yerindeyse İtilaf devletleri esírleri için "Anadolu'da zorunlu misafir olarak kaldılar" demek yerinde olacaktır. Elbette savaş koşullarının imkânsızlıkları, hastalıklar ve benzeri

\footnotetext{
28 Akkor, ...İngiliz Esirleri ve Esir Kamplar1, s.62-64

29 Akkor, ...Türk Esir Kampları, s.39-40

30 Akkor, ...Ingiliz Esirleri ve Esir Kampları, s.72-73
} 
sebeplerden dolayı hayatlarını kaybeden esirlerin savaş şartlarının acı gerçeklerinden biri olması göz ardı edilemez ${ }^{31}$.

Osmanlı Devleti, esirlerin - bilhassa subayların - rahat etmeleri için gerekli tüm şartları hazırlamaya özen göstermekte, gerekli kolaylıkları sağlamaya çalışmaktadır. Mesela Afyonkarahisar'da bulunan esirler yiyeceklerini ya garnizon komutanlığı vasitasiyla tekâlif-i harbiye suretiyle satın almakta ya da bizzat dışarıdan tedarik ederek bir şirket vasıtasıyla İstanbul' dan getirebilmektedirler. Bu konuda tamamen serbest bırakılmışlardır. Esirler de memnuniyetlerini dile getirmekten çekinmemişlerdir. Yalnızca şikâyetçi oldukları konu kendilerine gönderilen kolilerin bir kısmının kaybolması veya zamanında gelmemesidir. Ayrıca dini ihtiyaçlarını giderebilmeleri için garnizonda iki Katolik papaz istihdam edilmiştir. Konya'da bulunan esirler otellere yerleştirilmiş, otel ücreti Osmanlı Devleti’nce ödenmiştir. Buradaki esirler ayda üç defa çarşı hamamına götürülmekte, geziye çıabilmekte ve futbol oynayabilmektedirler ${ }^{32}$.

Esir sayısının artışına bağlı olarak Rusya'da da benzer bir uygulamaya gidilmiştir. İlk önce askerí kışlalar esir kampı olarak kullanılmış ancak ihtiyaç artınca hapishaneler, atıl durumdaki fabrikalar kullanılmıștır. Fakat bunlar da ihtiyacı karşılayamayınca bu sefer "dom" adı verilen sivil evler kiralanmaya başlanmıştır. Dom yönteminde dikkat edilen husus evlerin müstakil olmasıdır. Daha çok Ufa, Tiflis, Moskova, Yaroslav ve Kostroma şehirlerinde uygulanan dom yöntemine göre iki veya üç odalı evlerde 20-30 Türk subayı iskân edilmekte iken ${ }^{33}$ Türkiye'de bulunan evlerde en az altı, en fazla 9 kişi kalmıştır ${ }^{34}$. Bu sayılar ilgili devletlerin esirlere yaklaşımını göstermesi bakımından önem arz etmektedir.

- Daha savaşın başlarından itibaren Osmanlı esirlerine kötü muamelelerde bulunulduğu Baş Kumandan Vekili Enver imzasıyla 6 Temmuz 1331 (19 Temmuz 1915) tarihinde Hariciye Nezaretine gönderilen bir yazıdan açıkça anlaşılmaktadır. Yazıda İngilizlerin, elindeki Osmanlı esirlerini Türk, Kürt, Arap olarak ayırdıkları ve bunları ayrı ayrı yerlere gönderdikleri, siyasi cemiyetlerden hangisine mensup olduklarını, özellikle Türk esirlere zulmettiklerini ve bunun şiddetle protesto edildiği ve bunun Amerika sefareti aracilığıyla Ingilizlere bildirilmesi istenmektedir ${ }^{35}$. 17 Ağustos 1331 tarihli bir başka belgede ise Çanakkale'de esir alınan Osmanlı subay ve askerlerine İngiliz ve Fransızların kötü muamelede bulundukları ve bunlara karşı gerekli tedbirlerin alınması gerektiği ifade edilmektedir ${ }^{36}$.

Harbiye Nazırı Enver imzasıyla Hariciye Nezaretine yazılan 23 Nisan 1331 tarihli bir başka yazıda ise 5 Ağustos 1330 tarihinde Bombay'a varmış olan ve yakalanarak İngilizlere esir düşen Karadeniz Vapuru tabibi Doktor İsmail'in yazmış olduğu rapor doğrultusunda

31 Nuri Köstüklü, "Birinci Dünya Savaşında Polonya'da Şehit Olan Türkler ve Türkiye'de Ölen Polonyalı Askerler", Türkiye Polonya İlişkilerinde Temas Alanları Uluslararası Konferansı 1414- 2014, Bildiriler Kitabı, Türk Tarih Kurumu yay., Ankara 2017, s.337

32 Çapa, $a, g, m$, s. $51-52$

33 Kutlu, a.g.t, s.92-93

34 Akkor, ...Kocaeli'de Ingiliz Esirler, s.861

35 BOA, HR.SYS, D:2411 G:34

36 BOA, HR.HMŞ.IŞO D:43 G:22 
durumun Amerika sefareti aracılığıyla şiddetli bir şekilde protesto edilmesi isteğidir. Doktor İsmail, üç buçuk ay esir kaldıktan sonra Cidde'ye bırakılmış ve arkadaşlarıyla (70 kişi) beraber İngilizlerin çok kötü muamelelerińe maruz kalmıştır. Raporda İngilizlerin kendilerine yaptıkları zulümleri anlatan Doktor İsmail, çoraplarına kadar arandıklarını, kümeslere konulduklarını, tuvalet ihtiyaçlarının kendilerine verilen tenekeler vasıtasıyla giderildiğini ve bunların kendilerince döküldügünü, çay içmeye -ki sıcak sudan başka bir şey değil - izin verilmediğini, geceleri lamba verilmediğini, gazete ve kitap okumaya müsaade etmediklerini anlatmaktadır ${ }^{37}$.

Osmanlı Devleti, esir aldığı kişilere son derece insani bir muamele yapmakta iken Ingiltere'nin Osmanlı Devleti için yürüttüğ̈̈ asılsız propagandalar, askerlerin ruh halini derinden etkilemiş ve Osmanlı Devleti'ne karşı daha hırçın olmalarına neden olmuştur. Yalan yanlış beyanatlarla Kahire, Sidney, Melburn, Vellington ve Londra gibi büyük şehirlerde yayınlanan gazetelerde Türkler aleyhine ön yargılı kamuoyu oluşturulmaya çalıșılmıştır. Gazetelerde Türklerin, acımasız, vahşi ve barbar oldukları, savaş esirlerine kötü davrandıkları ifadelerine sıklıkla yer verilmişti ${ }^{38}$. Benzer uygulamalar Ruslar tarafından da yapılmıştır. Soğuğa, açlık ve susuzluğa terk edilen esirler - ki zaten çoğu hastadır - ölüyor ve bunlar olay ortaya çıkmasın diye yakılmışlardır ${ }^{39}$. Dahası İtilaf Devletleri'nin kurduğu garnizonların çoğu tel örgülerle çevrilidir. Hindistan'daki esirlerde tel örgü hastalığ 1 denilen kolay heyecanlanma, çabuk kızma, alınganlık, içe dönüklük gibi semptomlar gösteren, intihara veya cinayete kadar varabilen bir psikolojik rahatsızlık görülmekte olup bu rahatsızlık esirlerin psikolojisini bozmuş ve hatta intihar girişimlerine neden olmuştur ${ }^{40} .1917$ y1lında Gazze'de İngilizlere esir düşen mülazım-1 evvel Halit Bey, hazırlamış olduğu raporda esirlere yemek olarak sadece turşu verildiğini, esirlerin çok ağır işlerde çalıştırıldıklarını, hasta esirlerin Rum ve Ermeni doktorlara tevdi edildiğini, bundan dolay1 Türk esirlerin yüzde otuzunun gözlerinin kör olduğunu, yüzde onbeş, yirmisinin de zehirlenerek öldürüldügünü ifade etmektedir ${ }^{41}$.

Benzer uygulamalar Rus ordusunda da görülmektedir. Rus ordusuna mensup askerlerin bir kısmı uluslar arası hukuk kuralları çerçevesinde hareket ederken büyük bir kısmı savaş hukuku kurallarını görmezden gelerek Türk esirlere insanlık dışı muamelelerde bulunmuşlardır. Örneğin Rus askerleri, Osmanlı ordusundaki Kürtlerin, Rus esir ve ölülerine kötü muamele ettikleri gerekçesiyle esir aldıkları Kürtleri öldürmüşlerdir. Bununla birlikte esirlerin şahsi malları yağmalanmış, apoletleri sökülerek ayaklar altında çiğnenmiş, dinlerine, hükümetlerine, devletlerine küfür edilmiş ve her türlü hakarete maruz kalmışlardır ${ }^{42}$. Hatta hastanelere götürülen esirler çırıl çıplak soyularak ölüme terk edilmiş, ilgisizlik bir yana darp edilmiş ve daha da ileri gidilerek kasten öldürmeler gerçekleştirilmiştir. Hatta Türk subaylar yeri geldikçe taş veya kırbaçlarla darp edilmiş, şikâyet dilekçeleri işleme

37 BOA, HR.SYS, D:2247, G:6

38 Akkor, .... Ingiliz Esirleri ve Esir Kampları, s.73-74.

39 Kutlu, a.g.t, s.54

40 Zafer Sen, "I.Dünya Savaşında Osmanlı Esirleri ve Dramları", http://www.zafersen.com/birinci-dunya-savasindaosmanli-esirleri-ve-dramlari.pdf (Erişim tarihi 04.01.2018)

41 Arıkan, $a, g, m$, s. 37

42 Kutlu, $a, g, t$, s.22-28 
konulmayarak yırtılıp atılmıştır ${ }^{43}$.

Ruslar ele geçirdikleri Kars Hastanesi'nde yaralılara dahi zulmetmekten çekinmemişlerdir. Gelen mektuplara bakıldığında yaralıların bayıltılmaksızın ameliyat edildiklerini, kol ve bacaklarının bilinçli olarak kesildiğini, pansumanlarının yapılmadığını veya çok geç yapıldığını, yaraların iyileşmesi için herhangi bir müdahalede bulunulmadığını, yaralar kangren olduktan sonra müdahalede bulunulduğunu, sargıların herhangi bir malzeme kullanılmadan çekilerek çıkarıldıklarını ve iyileşmeye yüz tutmuş olan yaraların tekrar açıldığını ögrenmekteyiz ${ }^{44}$.

Rusların bu tarz davranışları Osmanlı Hükümetine şikâyet edilmektedir. Hariciye Nezareti'ne yazılan bir yazida Rusya'da Kostroma ${ }^{45}$ eyaletinde esir bulunan Ayetullah imzasıyla gelen 26 Ağustos 1917 tarihli bir yazıda Osmanlı esirlerine kötü muamele yapıldığı ve buna Türkiye'deki Rus esirlerine de aynı şekilde davranılması hususundaki talebi iletilecek ${ }^{46}$ ve buradaki Osmanlı esirleri için gereğinin yapılması istenecektir ${ }^{47}$. Makedonya ve köylerinden Burgaz'a sevk edilen sivil Müslüman halk da kendilerine kötü muamelelerde bulunulduğuna ilişkin şikâyetlerde bulunmuşlardır ${ }^{48}$.

İtilaf devletlerinin aksine Osmanlı Devleti, gerek asker gerekse sivil esirlere daha insani koşullar hazırlamaya çalışmış ve bu konuda gerekli tedbirleri almıştır. Osmanlı Devleti'nin yayınladığı Üsera Talimatnamesi'nin 4.maddesinde; "Esir subaylar, imkânlar ölçüsünde şereflerine uygun otel ve konaklara yerleştirilir. Esir subaylar, ihtiyaçlarını kendileri karşılayamazlarsa, istekleri halinde bunların ihtiyaçları Osmanlı hükümeti tarafindan karşılanır" ifadesiyle esir subaylara yakışır konak ve otellerde ikamet ettirilmeleri gerektiği açıkça ifade edilmektedir ${ }^{49}$. Bir başka ifade ile Osmanlı Devleti, elinde tuttuğu esirlere savaştı̆̆ asker gözüyle değil kimi durumda bir misafir edasıyla yaklaşmıştır.

İngilizlerin Osmanlı askerlerini dikenli tellerin ardında tuttuğu kampların aksine İngiliz esirler, şehir merkezlerinde otellerde ve evlerde kalmışlardır. Hatta Bursa ve Eskişehir gibi kamplarda esirler, muhafızsız olarak şehir merkezinde rahatça dolaşabilmektedirler ${ }^{50}$. Bunun yanında dini özgürlükler konusunda kısıtlama getirilmemiş, gereken kolaylıklar sağlanmıştır. Esirler, asayiş tedbirlerine uymak koşuluyla ve "din ve mezheplerine ait mabette hazır bulunmak ta dâhil olmak üzere ayin-i mezheplerinin icrasinda serbest-i tammeye mazhar" olmaktaydılar ${ }^{51}$.

43 Kutlu, a,g,t, s. 135 ve 164

44 Osmanlı Belgelerinde Birinci Dünya Harbi C.1, s.301-306

45 Rusya Federasyonu'nun batı kesiminde, Volga Nehri kıyısında, Moskova'nın 320 km kuzeydoğusunda yer alan bir kent (https://tr.wikipedia.org/wiki/Kostroma (Erişim Tarihi: 04.01.2018)

46 BOA, DH.EUM.5.Şb, D:61, G:2

47 BOA, HR.SYS, D:2206, G:6

48 BOA, HR.SFR.04, D:491, G:26

49 Alaattin Uca, "1915 Yılında Yayımlanan Bir Üsera Talimatnamesi ve Düşündürdükleri”, A.Ü. Atätürk İlkeleri ve Inkllâp Tarihi Enstitüsü Atatürk Dergisi, Cilt 3, Sayı 3, Erzurum 2003, s. 175

50 Özçelik, a.g.t, s.50-51; Akkor, ...Ingiliz Esirleri ve Esir Kampları, s.75

51 Çapa, $a, g, m, \mathrm{~s} .49$ 
Osmanlı Devleti'nin bazı noktalarda esirlere bazı kısıtlamalar getirdiği de görülmektedir. Mesela bunlardan birisi esirlerin gönderecekleri mektup veya kartların denetlemeden geçirilmesidir. Casusluk ihtimalinée karşı mektup veya kartlar Dersaadet Sansür Müfettişliği tarafından incelenmekte, sakıncalı görülenlere el konulmaktadır. Bir başka uygulama ise esirlerin sürgün noktalarına gelişigüzel yerleştirilmemesi ve istihdam edilmemeleridir. 1917 yılında yayımlanan bir genelge ile askeri personelin düşman devlet tebaası veya tarafsız devletler tebaası ile aynı yerde ikamet etmeleri yasaklanmıştır. Ayrica esirlere gönderilen para, eşya ve kıymetli maddelerin dağıtımı belirli kurallar çerçevesinde gerçekleştirilmiştir ${ }^{52}$. Örneğin Hariciye Nezareti'ne yazılan bir yazıda yabancı esirler namına gelecek meblağın Cenevre'deki Federal Bank'ta Hilal-i Ahmer hesabına yatırılması, listenin ya mezkûr banka veyahut uluslar arası Salib-i Ahmer vasitasıyla Hilal-i Ahmer'e verilmesi gerekmektedir. Paraların ise Hilal-i Ahmer vasitasıyla ya garnizon kumandanlıklarına ya da esir hasta ise hastane baştabibine makbuz karşılığında verilmesi gerekmektedir ${ }^{53}$.

Esirlere gönderilen eşya, yiyecek ve para işleriyle genelde Hollanda, Amerikan sefareti ${ }^{54}$ ile tarafsız olan diğer devletlerin sefaretleri ve Cenevre Uluslararası Kızılhaç Cemiyeti ilgilenmiştir ${ }^{55}$. Esirlerin para ve değerli eşyaları makbuz karşılığı üsera komisyonlarınca saklanmış, kendilerine ihtiyaçları oranında yine makbuz karşılığında paraları ihtiyaçları oranında verilmiştir. Esir subaylar nakit ve değerli eşyalarını emaneten kasaya bırakmak veya kendi ellerinde tutmak hususunda serbest bırakılmıştır. Harp esirleri tarafından gönderilen mektuplar, havaleler, posta paketleri her türlü ücretten muaf tutulmuş, esirlere ait hediye ve yardım olarak gönderilen eşyalardan gümrük vergisi alınmamış, Osmanlı Hükümeti'nce işletilen yollarda esirlerden yol ücreti talep edilmemiştir. Esirlerin gönderdikleri veya kendilerine gelen her türlü madde sansüre tabi tutulmuş, sakıncah görülenler iade edilmemiştir. Asayiş tedbirlerine uygun olmak şartıyla esirlerin din ve mezhebine ait mabetlere gitmelerine, dini ayinlerini yapmalarına izin verilmiştir. Esirlerin yiyeceklerini kendi mezheplerinin icaplarına göre seçmelerine ve pişirmelerine de müsaade edilmiştir ${ }^{56}$. Ancak esirlerin bazı ihtiyaçlarının karşılanamadığı durumlarda olmuştur. Mesela Eskişehir'de Anadolu askeri hattı komiserliğinde çalışan Rus esirler için istenilen battaniyeler gönderilememişti ${ }^{57}$.

\section{Esirlerin Çalıștırılması}

Lahey Sözleşmesi'nin esirlerle ilgili 6. maddesi; "Devlet, savas esirlerini subaylar hariç, rütbe ve kabiliyetlerine göre işşi olarak kullanabilir. Ancak bunlara yaptırllacak işler aşırı derecede yorucu ve savaş operasyonlarıyla ilgili olmayacaktır. Esirler kamuya, özel kişilere ya da kendi hesaplarına çalışabilirler. Devlet için yapılan işlerin karşılığı, yürürlükte olan şekliyle, milli orduda ayn işi yapan askerlere ödenen miktar üzerinden esirlere ödenir veya orduda yapılan işler karşılığında para ödenmiyorsa, yapılan benzer işler tarifesi üzerinden ödeme yapılır. Esirlerin aldıkları ücret durumlarını iyileştirmede

52 Sonat, $a, g, m$, s. $270-273$

53 BOA, HR.SYS D:2213 G:3

54 Çapa, $a, g, m$, s. 54

55 Akkor, ...Ingiliz Esirleri ve Esir Kamplarl, s. 82

56 Uca, a.g.m, s.176; Çapa, a,g,m, s.52

57 Arslan, a.g.t, s. 140 
kullanılacaktır artanı ise iaşe masrafları düşüldükten sonra serbest bırakılmaları esnasında kendilerine ödenecektir" şeklindedir ${ }^{58}$.

Savaş şartlarının oluşturduğu ortam içerisinde var olan işlerin devamı ya da yenilerinin yapılabilmesi için iş gücüne ihtiyaç vardır. Ancak içinde bulunulan ortam gereği yeterli çalışan bulmak da son derece zordur. İşte bu işgücü eksiğini savaşan devletler savaştıkları devletlerden almış oldukları esirlerle giderme yoluna gitmiştir. İngiltere, Osmanlı Devleti'nden almış olduğu esirlerin bir kısmını Burma'da yol yapımı ve bahçe ziraatı işlerinde kullanmıştır. Yine Burma' da tutulan Türk esirlerden 3.000 tanesi AungbanHeho arasında demiryolu yapımında çalıştırılmıştır. Akdeniz havzasına gelindiğinde İngilizlerin yönetimi altında Kıbrıs'ta esaret hayatı yaşayan Türk esirleri; ormanlarda ağaç kesimi, Mağusa surlarının tamiri ve maden ocaklarında çalışma gibi farklı birçok işlerde çalıştırılmıştır ${ }^{59}$.

Fransızlar, Türk esirlerini bağ bahçe işlerinde ve tren yolu yapımında kullanmayı düşünmüşlerdir. Çeşitli bölümlere ve gruplara ayrılan esirler, farklı bölgelere dağıtılmıştır ${ }^{60}$. Ancak 18 Temmuz 1331 (31 Temmuz 1915) tarihli bir belgede Gelibolu yarımadasinda İngiliz ve Fransızlar tarafindan esir edilen Osmanlı askerlerine insanlık ve hukuk dışı muamelede bulunulduğu ve bunlara insani bir şekilde davranılması istenirken ${ }^{61}$ Hariciye Nezareti'ne yazılan 6 Ağustos 1331 (19 Ağustos 1915) tarihli bir belgede de Fransizların aldıkları Osmanlı esirlerini angarya işlerde çalıştırdıkları ve bu durumun şiddetle protesto edilmesi istenmektedir ${ }^{62}$.

Osmanlı Devleti de bazen esirleri çalıştırmıştır. Savaş şartlarında amele ihtiyacının karşılanamaması ve Türk ordusu tarafından ele geçirilen esirlerin sayıca fazlalığı ve bunların iaşe ihtiyaçlarının karşılanmasındaki zorluklardan dolayı Uluslararası Lahey Sözleşmesi ve Esir Talimatnamesi'nde belirtilen şartlar çerçevesinde Osmanlı Devleti, esirlerin bir kısmını Toros Tünellerini yapan şirketin emrine vererek çalıştırmaya başlamıştır ${ }^{63}$. Subaylar, her

58 Kutlu, a.g.t, s.XXIX

59 Akkor, ...Ingiliz Esirleri ve Esir Kampları, s.95

60 Fransa' daki esirkampları Beziers MerkezDeposu, Motte, Boujan, Borgo, Ortale Calıșma Kampı Pradelaine Çalıșma Kampı Mas Du Ministre Çalışma Kampı Korsika Adası'ndaki Esir Kampları, Bastia Subay Merkezi, Casabianda Merkez Deposu. Sivil Türk Esirleri ise De Lounge, Pontmain ve La Chartrouse Kamplarında bulunmaktaydı. Romanya'da bulunan esir kamplarının isimleri ise șöyle idi: Dobrovat, Sipote, Barland, Mascatani. Bilgi için bak. Akkor, ...Türk Esir Kampları, s.174 vd. Hilal Ahmer Cemiyetinden Hariciye Nezaretine yazılan 2 Temmuz 1918 tarihli yazıda Fransa'da bulunan Osmanlı harp esirleri genellikle Korsika Adasıyla Beziers șehri civarında çiftliklerde, Ingiliz Hükümeti elinde bulunan Osmanlı esirleri ise Mısır, Hindistan, Kıbrıs, Malta ve Selanik'te bulunmaktadır. En fazla esir ise Mısır ve Hindistan'da olup buralarda yaklaşık 50.000 kadar esir bulunmaktadır. Bilgi için bak. BOA, HR.SYS D:2242 G:2

61 BOA, HR.SYS D:2189 G:1

62 BOA, HR.SYS D:2189 G:2

63 Özçelik, a.g.t., s.107 vd. Arslan, a.g.t, s.88-100. Örneğin bu yerlerden birisi olan Pozantı’nın Belemedik Köyünde Almanlarca kurulan esir kampında her türlü ihtiyaç karşılandığı gibi burada hastane, kilise, cami, sinema ve yeni evler inşa edilmiştir. Burada tutulan esirler, yerli iş̧̧ilerle birlikte tünel kazılarında çalışmışlardır. Hatta 1917 yılında köy nüfusu işçiler, köylüler, Alman yetkililer ve askerler dâhil olmak üzere 35.000’lere ulaşmıştır. Bilgi için bak.Köstüklü, “...Polonya'da Şehit Olan Türkler...”, s.349 (36 nolu dipnot)

Benzer şekilde Türk esirlerde çeşitli işlerde çalıştırılmaktaydı. Rusya'daki Türk subaylarına iaşe ve diğer masraflar karşılığında verilen maaşlar şu şekildedir. 
türlü hizmetten muaf tutulurken erler yeteneklerine göre devletçe belirlenen bir ücret karşılığında çalıştırılmaktayd $1^{64}$. Bunun yanında ülkenin değişik yerlerindeki çiftliklerde, ziraat işlerinde, belediyelerin temizlik işlerińde, seyyar hastanelerde, madenlerde, Haydarpaşa İstasyonu inşaatında, limanlarda, Ankara- Sivas şimendifer hattı inşaatında, Kütahya-Tavşanlı şose yolu yapımında ve orman işletmeleri gibi farklı işlerde de değişik milletlerden esirler çalıştırılmıştır. Bazı dönemlerde de Meclis-i Vükela kararı ile Osmanlı Devleti'nin müttefiki olan Almanya'nın elinde bulunan Türk asıllı Müslüman Rus esirler Lüleburgaz ve Eskişehir'deki çiftliklerde istihdam edilmek üzere Türkiye'ye getirilmiștir. Buna karşılık Türkiye'de bulunan Rus esirler arasında Alman ve Hıristiyan olanlar da Almanya'ya gönderilmiştir ${ }^{65}$. Almanya ve Avusturya'da bulunan esirler 10 veya 20 kişilik gruplar halinde Türkiye'ye gönderilmiştir ${ }^{66}$.

Savaş yıllarında gerek ittifak gerekse itilaf grubunda olsun esirler yabancı dil öğretmeni, terzi, marangoz gibi işlerde de çalıştırılmışıır ${ }^{67}$. İşin ilginç noktalarından birisi de çalıştırılmak için götürülen esirlerden işe yaramayanların kamplara geri gönderilmesidir. Bağdat hattı inşaatlarında çalıştırılmak üzere götürülen esirlerden işe yaramayanlar Afyonkarahisar kampına geri gönderilmişlerdir ${ }^{68}$. Esirlerin çalışma saatleri de mevsimlere göre değişkenlik göstermektedir. Darıca Çimento Fabrikasında çalışan esirler kış aylarında günde 10 (on) saat çalışırken yazın 10,5 (on buçuk) saat çalışmaktadır. Günlük 5-10 kuruş alan esirler, işlerin yoğun olduğu dönemlerde Pazar günleri de çalıştırılmıştır ${ }^{69}$.

Esirler arasından özellikle Müslüman olup ihtiyacı olanlar değişik yerlerde ücret karşılığında çalıştırılmıştır. Değişik yerlerde çalıştırılan bu esirlerin firar etmelerini önlemek amacıyla Başkumandanlık Vekâleti’nin isteği üzerine 12 Mart 1333 (1917) tarihinde, Dâhiliye Nazırı Talat Paşa imzalı bir genelge yayınlanarak emlak sahiplerine verilen esirlerin, fotoğraflarının alınması gibi firarlarına mani olacak tedbirlerin alınması ve çiftlik sahiplerinin uyarılması istenmiştir. Başkumändanlık Vekâleti, esir subaylar arasında firar hadiselerinin yaygınlaşmasından dolayı esirlerin sahil ve şimendifer hattından uzak mahallerde ikamet ettirilmeleri için vilayetleri uyarmıştır. Esirlere, aileleri ve yardım kuruluşları tarafından gönderilen kolilerde esirlerin firar etmesini kolaylaştıracak eşyaların olmaması için koliler sıkı bir şekilde kontrol edilmiş, hatta gönderilen paralar esirlere ihtiyaçları kadar verilmiştir. Esirlere birden fazla elbise verilmemesi ve yerli ahali elbisesi

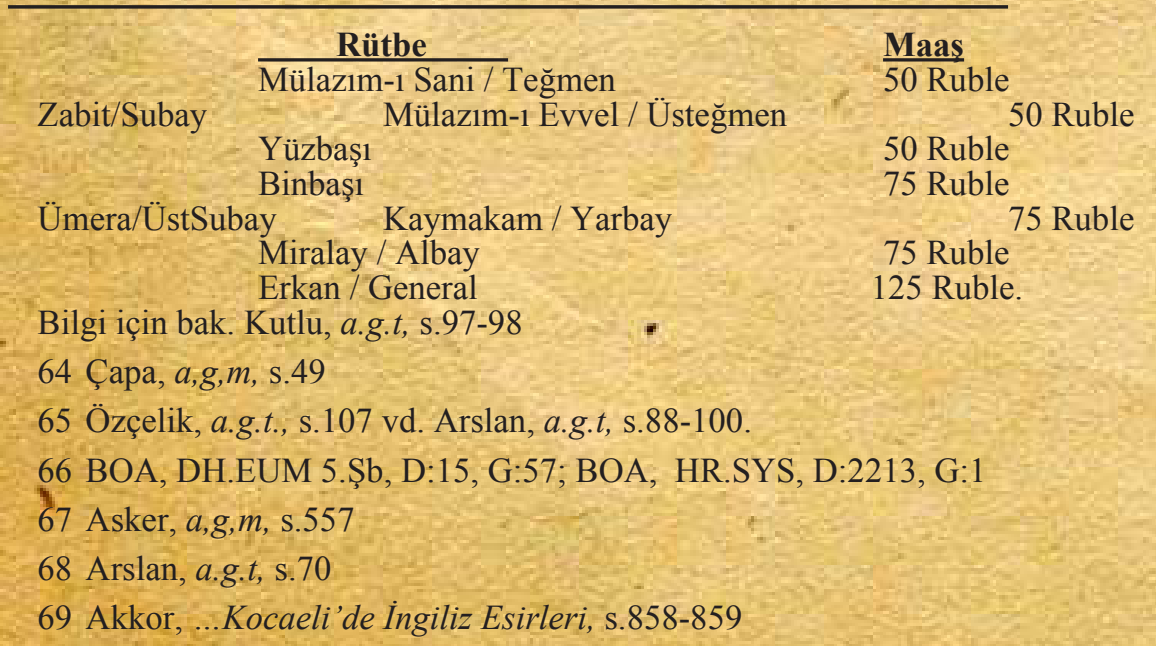


giymelerinin yasaklanması da firar etmelerini önlemeye yönelik alınan bir diğer tedbirdir ${ }^{70}$. Firarları önlemeye yönelik alınan önlemlerden birisi de sabah güneş doğmadan, akşam ise saat dokuzdan sonra sokağa çıkma yasağıdır ${ }^{71}$. Yemen'de esir düşen Hasan Çavuş, hatıralarında akşamları firarları engellemek için gözlerine ilaç sıkıldığını belirtmektedir ${ }^{72}$.

Şunu belirtmekte yarar vardır. Osmanlı topraklarında bulunan esirler firar girişimlerinde bulunurken İtilaf devletleri elinde bulunan Türk esirler de zaman zaman firar teşebbüslerinde bulunmuşlardır. Rusya'da Nargin Adası'nda bulunan esirlerin bir kısmı burada faaliyet gösteren Bakü Cemiyet-i Hayriyesi'nin yardımlarıyla kaçırılmış, bunun açığa çıkması üzerine cemiyetin faaliyetleri kısıtlanmıştır. Tabii ki yakalandıklarında çok kötü cezalara maruz kalınmakta, hatta bedeli hayatları olmaktadır. Bununla beraber kaçmalarına yardım edenler de benzeri cezalara çarptırılmışlardır ${ }^{73}$. Mesela Kıbrıs'ta bir imam bu sebeple tutuklanmıştır ${ }^{74}$.

Tarafsız bir heyet olarak Osmanlı Devleti'nde bulunan esir garnizonlarını gezen Kızılhaç heyetinin raporlarına göre esirler garnizonlardaki komutanlarının tavırlarından son derece memnundurlar. Esirler her gün yürüyüş ve fiziksel egzersizler yapabilmekte ve özellikle de İngiliz esirler futbol oynayabilmektedir. Esirler belli aralıklarla bulundukları şehri gezebilmekte ve alışverişe çıkabilmektedirler ${ }^{75}$. Kocaeli Eskihisar esir kampında bulunan bir İngiliz' in Hollanda Büyükelçiliği'ne yazdığı bir mektupta yazdığı "Türkiye 'deki en iyi yerlerden biri olan burada oldukça iyi durumda ve rahat olduğumuzu söylemekten memnuniyet duyarım" sözleri esirlere olan yaklaşımın açık bir ifadesidir ${ }^{76}$.

\section{Savaş Yıllarında Mübadele Çalışmaları}

Birinci Dünya Savaşı süresince, savaşan devletler için sorun oluşturan işlerden birisi de çıkarılan esir listelerinin karşılıklı paylaşımıdır. Bu problemleri çözmek için yapılan girişimler neticesinde esir listelerinin karşılıklı değişiminin yapılabileceği İngiltere ve Fransa hükümetleri tarafından kabul edilmiştir. Bu gelişmelerden sonra savaşan taraflar, esir listelerinin oluşturulması ve esirlerin karşılıklı olarak kolaylıkla paylaşımı amacıyla Salib-i Ahmer ve Hilal-i Ahmer cemiyetlerinin bu işi gerçekleștirmesini kabul etmişlerdir. $\mathrm{Bu}$ durum Osmanlı Devleti'nin Lahey Sözleşmesi hükümlerini yerine getirdiğini

70 Özçelik, a.g.t, s.59-61; Arslan, a.g.t, s.134-135. Osmanlı Devleti'nde esirlere birden fazla elbise verilmezken Rusya'da bulunan Osmanlı esirleri elbise sıkıntısı çekmekteydi. Bunun için Osmanlı Harbiye Nezareti temsilcisi Seyfi Bey Alman Harbiye Nezareti temsilcisi General Frederich'ten 25.000 kışlık elbise sözü almıştı. Akçura, ...Rapor, s.4. Zaten esirlerin hemen hepsi sağlık koşullarının yetersizliğinden, hasta ve sakatların fazlalığından ve en çokta elbiseye ihtiyaçlarının olduğundan bahsetmektedirler. Akçura, ...Rapor, s.9. Ayrıca esirlerimizin çektiği elbise sıkıntısı Akçura'nın raporunda şu sözlerle ifade edilmektedir. "Kış başlıyordu. Esirlerimizden bazılarının iç çamaşırları bürudete(soğuk) karşı mahfuz için kifayet edemeyecek bir halde idi. "Akçura, ...Rapor, s.55

71 Sonat, $a, g, m, \mathrm{~s} .271$

72 Arıkan, $a, g, m$, s. 37

73 Kutlu, a.g.t, s. 294-300

74 Zafer Sen, "I.Dünya Savaşında Osmanlı Esirleri ve Dramları", http://www.zafersen.com/birinci-dunỷa-savasindaosmanli-esirleri-ve-dramlari.pdf (Erişim tarihi 04.01.2018)

75 Özçelik, a.g.t, s. 99

76 Akkor, ...Kocaeli'de Ingiliz Esirleri, s.860 
göstermektedir ${ }^{77}$. Daha savaşın başlarında Osmanlı Devleti, Prut ${ }^{78}$ gemisinden esir aldığ 1 Doktor Vladimir İvanoviç Aleksin ile Salim Efendinin mübadelelerini uygun görmüş ve mübadelenin gerçekleşmesi için gerekli girişimlef́de bulunmuştur ${ }^{79}$.

Tarafların birbirinden aldıkları esirler arasında, savaş sırasında yaralanmış ve esir kamplarında gerekli özenin gösterilememesinden dolayı hastalanmış esirler de bulunmaktaydı. Savaşan ülkelerde kurulan esir kamplarının yaşam şartlarının düzeltilmesine yönelik tarafsız ülkeler ile Salib-i Ahmer ve Hilal-i Ahmer cemiyetlerinin yaptığ çalışmalar sırasında öncelikli olarak bu sakat ve hasta esirlerin durumları görüşülmüş ve bu esirlerin mübadele edilmesi veya tarafsız ülkelerde tedavi amaciyla ikamet ettirilmesi gündeme gelmiştir. Birinci Dünya Savaşı_sırasında Osmanlı Devleti'ne esir mübadelesiyle ilgili yapılan ilk teklif, askerlik hizmetini yapamaz hale gelmiş esirlere yönelik Papalık tarafından yapılan tekliftir. Papalık tarafindan yapılan bu teklif hakkında Hariciye Nezareti, 27 Kânunuevvel 1914 tarihinde Başkumandanlık Vekâleti'ni bilgilendirmiştir. Başkumandanlık Vekâleti, Papalık makamının diğer hükümetler nezdindeki girişimlerinin sonuçlarının beklenmesinin münasip olacağını bildirmekle birlikte, Osmanlı Devleti, Papa'nın bu çağrısına olumlu yaklaşarak hasta ve malul esirlerin karşılıklılık esası doğrultusunda mübadele edilebileceğini 6 Şubat 1915 'te kabul etmiştir ${ }^{80}$. Harbiye Nazırı Enver imzasıyla Hariciye Nezaretine yazılan bir yazıda İngiltere'de bulunan sivil Osmanlı esirlerinden yardıma ihtiyacı olanların ihtiyaçlarının karşılanması amacıyla 500 Liranın gönderileceği ve Papa'nın esirlerimize yardım etmek istemesinin son derece memnuniyet verici olduğu ifade edilmektedir ${ }^{81}$. Benzer yardımlar Fransa'da bulunan Osmanlı esirleri için de yapılmıştır. Fransa'da bulunan sivil Osmanlı esirlerine ihtiyaçları için 28 Haziran 1332 tarihinde 50.000 kuruşluk bir meblağın İstanbul'daki Amerika sefaretine verilmesi kararı alınmıştır ${ }^{82}$.

Malul esirlerin durumuna ilişkin Papa, bireysel girişimlerini sürdürürken Osmanlı Devleti de Papalık makamının teklifi sonrasında her ne kadar resmi ikili bir antlaşma imzalanmamış olsa da muhtemel bir değişime tabi tutulabilecek esirlerin tespiti için çalışmalarına başlamıştır. Osmanlı resmi makamları değişim için gerekli çalışmaları yürütürken Papa, sadece esirlere yardım etmek ve onların durumunu yakından takip etmekle kalmayıp kimi zaman onların serbest bırakılması için girişimlerde de bulunmaktaydı. Örneğin Papa, Enver Paşa ile görüşerek denizci Teğmen Geoffrey FitzGerald'ın memleketine

77 Özçelik, a.g.t, s.46-48. Hilal-i Ahmer Cemiyeti'nin esirlerle ilgili işleri üstlenmesi 1916 y1lında gerçekleşecek ve 1918 yılına kadar esirlerle ilgili 14.000 tahkikatı sonuçlandırarak yılda 100.000 paketin esirlere ulaştırılmasında vasita olacaktır. Ayrıca esirlerin elbise ihtiyacından esir kamplarında okul açılmasına ve kitap, araç-gereç ihtiyaçlarına kadar birçok konuda faaliyet göstermiştir. Bak. Kutlu, a.g.t, s.254. Yusuf Akçura ise raporunda esirlerden bazılarının Rusya'da çıkan Türkçe gazeteleri kendi paraları ile aldıklarını belirterek onların bu sıkıntılarını gidermek adına gazete sahiplerine ve kitapçılara mektup yazdığını ancak esirlerin kitaba fazla merak görmediklerini ifade etmektedir. konuyla ilgili şu sözleri sarf etmektedir; "Umumiyetle esirlerimizde kitaba fazla merak görmedim. ...Esirler kitap ve ceride okumaktan ziyade mekatibeden haz ediyorlardl." Bak.Akçura, ... Rapor, s.26. Yine Akçura raporunda Hilat-i Ahmer vasitasıyla Rusya'daki esirlerimize verilmek üzer 49 Kur'an-1 Kerim ve 162 Türkçe ve Arapça kitap gönderildiğini belirtmektedir. Akçura, ...Rapor, s.6

78 Osmanlı Devleti'nin 29 Ekim 1914'te Rus limanlarını topa tuttuğu sırada batırılan Rus mayın gemisi.

79 BOA, DH.EUM.5.Şb, D:4, G:36

80 Özçelik, a.g.t, s.165-170; Akkor, ...Ingiliz Esirleri ve Esir Kamplarl, s.237-239

81 BOA, HR.SYS, D:2242, G:4

82 BOA, HR.SYS D:2247 G:43; BOA,HR.SYS D:2247 G:37 
gönderilmesini talep etmiştir ${ }^{83}$. Bununla beraber Osmanlı Devleti ile Fransa ve İngiltere arasında yapılan görüş̧melerde esir değişimi konusunda eşit davranılmamasına rağmen yine de Osmanlı Devleti'nde bulunan esirlerine kötü davranılmadığını göstermek hem de insani gerekçelerle 15 yaşını doldurmayan çocukların Osmanlı toprakları dışına çıkma istekleri kabul edilmiş ${ }^{84}$, buna karşın Papa'nın 16 yaşından küçük ve 50 yaşını geçmiş esirlerin değişimi teklifi İngiliz ve Fransızlarca kabul görmemiştir. Ayrıca İngilizlerin Osmanlı Devleti'ndeki esirlerinin serbest bırakılması karşılığında Osmanlı Devleti de bazı isteklerde bulunmuştur. Bu istekler Prens Ömer Tosun Paşa'nın serbest bırakılması, Eyüp Sabri ve Zinnun Beylerin tahliyesi, Bombay Baş şehbender Vekili Basri, Johannesburg Baş şehbenderi Remzi, Malta Şehbenderhanesi imamı Cemalettin ve Manchester fahri şehbenderi Rasim Efendi'nin serbest birakılması gibi isteklerdir ${ }^{85}$. Bununla beraber Osmanlı Devleti'nin bu iyi niyetlerine karşılık İngiltere ve Fransa gibi devletler Osmanlı Devleti'ne gelmekte olan vapurları durdurmakta ve silahaltına alınma çağına gelmeyen Osmanlı tebaasını savaş esiri sifatiyla tutuklamakta ve gayr-i insani muamelelerde bulunmuştur. Bununla yetinmeyerek savunmasız ve istihkâmsız sahiller topa tutulmuştur ${ }^{86}$. Ayrıca İngiltere, elinde bulundurduğu esirlerin bir kısmını haksız yere tutuklamıştır. Örneğin Hariciye Nezareti'ne Dahiliye Nazırı Talat imzasıyla yazılan 17 Teşrin-i evvel 1331 (30 Ekim 1915) tarihli bir yazıda İngiltere'nin elinde bulundurduğu 476 esirden yalnızca elli beş kişiyi serbest biraktığı ve 421 kişiyi tutukladığı bilgisine yer verilmektedir ${ }^{87}$.

1915 yılının sonuna doğru İngiltere, Almanya'ya teklif ettiği 13 maddelik esir değişim antlaşmasının bir suretini Amerika Büyükelçiliği aracılığıyla Osmanlı Devleti'ne de iletmiştir. Antlaşmaya göre; Bir ya da birden fazla uzvun kısmen veya tamamen kaybı, kasların yağlanması ya da zarar görmesi veya eklem sertleşmeleri, ciddi oranda hareket yeteneğini kaybedecek ölçüde omurganın zarar görmesi, damar sertleşmesi, askerlere eğitim veremeyecek seviyede olması, kalıcı felç nedeniyle oluşan sakatlık ya da hasarın devam etmesi, Omurilik'te kalıcı hasar, körlük, yaralanma neticesi göğüs kafesinde ağır hasar, ağır yaralanmalar, verem, tedavi edilemeyecek düzeyde beyin rahatsılıkları durumunda esir değişiminin yapılması öngörülmekteydi ${ }^{88}$.

Ingiltere, Osmanlı Devleti’ne esir değişimi teklif ettiği dönemde iade etmeyi planladığı askerlerin listesini oluşturmaya başlamıştır. İki devletin de yapıcı girişimlerde bulunmasına rağmen savaş şartlarının zorluğu nedeniyle olumlu bir sonuç elde edilememiștir. İlk ciddi teşebbüs başarısız olsa da esirlere dönük girişimlerden vazgeçilmemiştir. Osmanlı Devleti'nin elinde bulunan esirler için aracı olan devletlerin başında tarafsız olan İspanya, Amerika ve Papalık makamı gelmekteydi. 1917 yılı itibariyle Amerika'nın savaşa katılmasıyla Osmanlı Devleti'ne en çok yardım eden devlet olarak İspanya ön plana çıkmışıır ${ }^{89}$.

Dersaadet İspanya sefiri aracılığılla Romanya'nın Almanya, Avusturya ve Bulgaristan

83 Özçelik, a.g.t, s.165-170; Akkor, ...Ingiliz Esirleri ve Esir Kampları, s.237-239

84 BOA,HR.SYS, D:2239, G:3

85 BOA,HR.SYS, D:2240, G:1

86 Temel, $a, g, m$, s.152-153

87 BOA, HR.SYS, D:2978, G:27

88 Akkor, ...Ingiliz Esirleri ve Esir Kamplarl, s.239-240

89 Akkor, ....Kocaeli'de Ingiliz Esirleri, s.862-863; Akkor, ...Ingiliz Esirleri ve Esir Kamplarl, s.242 
ile malul ve yaralı esir değişimi konusunda görüşmeler yaptığı, Osmanlı Devleti'nin böyle bir görüşmede yer alıp almayacağı sorulmuş, akabinde Hariciye Nezaretinden Başkumandanlık Vekâleti' ne gönderilen 17 Temmuz 1333 tarihlíbir belgede durumun değerlendirilmesi istenmiş, verilen cevapta ise esir değişiminin kabul edildiği ifade edilmiştir ${ }^{90}$. Dahası İspanya Kralı, verem riski olan hasta esirlerin mübadelesini veya tarafsız bir memlekete gönderilmesi teklifinde bulunmuştur ${ }^{91}$.

Osmanlı Devleti, askeri gerekçelerden dolayı bazen esir değişimine olumsuz cevap vermiștir. Kut'ül-Amâre'de Ingilizlerce esir edilen Osmanlı memurları ile Bağdat'ta alıkonulan İngiliz ailelerinin değişimini muvafik görmemiştir. Sebebi ise İngilizlerin savaş hukukunu hiçe saymalarıdır. Şöyle ki hastaneler bombalanmakta, yaralıları taşıyan gemilere ateş edilmekte, savunmasız şehirleri bombalanarak çocuklar katledilmektedir. Başkumandan vekili Enver imzasıyla Hariciye Nezareti'ne 14 Temmuz 1331 tarihinde yazılan belgede İngilizlere karşı1ık misli bir şekilde cevap verileceği ifade edilmektedir ${ }^{92}$.

Osmanlı Devleti ile İtilaf devletleri arasında yapılan görüşmeler neticesinde kimlerin malul sayılacağı konusunun halledilmesiyle 24 Aralık 1915 tarihinden sonra Osmanlı sinırları dahilinde bulunan esirlerden maluliyet şartlarını taşıyanların muayenelerinin yapılmasına ve sayılarının tespit edilmesine başlanmıştır. 1916 Nisan ve Mayıs aylarında mübadele edilecek esirler tespit edilmiştir. Ancak yapılan çalışmalar 1917 yilında Kopenhag'ta yapılacak konferansa kadar nihai bir sonuç vermeyecektir. 1917 yılında yapılan Kopenhag Konferansı'na Osmanlı Devleti adına Rauf (Orbay) başkanlığında Yusuf Akçura, İzzet ve Seyfi Beylerden oluşan bir heyet gidecek ve yapılan müzakereler neticesinde 2 Kasım 1917 tarihinde bir sözleşme imzalanacaktır. Burada malul esirlerin ivedilikle mübadele edilmesi kararlaştırılmıştır. Sözleşmeden sonra karargâh-1 umumi riyasetine sunulan bir raporda mübadele edilecek listede 13 Romen, 81 İngiliz, 30 Rus ve 1 Fransız olmak üzere 125 esirin Rusya' dan gelecek 250 Osmanlı esiriyle değiştirilmesi kararlaştırılmıştır ${ }^{93}$. Daha sonra ittifak grubu devletleri ile Rusya arasında 25 Ocak 1918'de Petrograd Sözleşmesi imzalanmıştır. Sözleşmeye göre; askerlik mesleğini ifa edemeyecekler, herhangi bir uzvunu (el veya ayak) veya gözlerinden birisini kaybedenler, kötürüm olanlar, akıl ve sinir hastaları gibi hususlara malik olanlar derhal iade edilecektir. Ayrıca sivil esirlerle ilgili olarak kız çocukları ve kadınlar, 16 yaşından küçük, 45 yaşından büyük erkekler, yaşı ne olursa olsun din adamlarının derhal mübadele edilmesi gerekmektedir ${ }^{94}$. Ancak yapılan tüm çalışmalara rağmen Petrograd Sözleşmesi'nde esir mübadelesi işi çözülemeyince meseleyi tekrar görüşmek üzere Moskova' da bir toplantı yapılması kararlaştırılmıştır. Almanya bu müzakerelerde eldeki esirlerin bire bir mübadele edilmesini ve kalan her bir esir için 2.000 mark tazminat ödenmesini teklif edecektir. Osmanlı Devleti ve Rusya bu teklife karşı çıkacaklardır. Örneğin müzakereler devam ettiği sıralarda Osmanlı Devleti'nin elinde 124 subay ile 4.500 er olmak üzere toplam 4.624 Rus esiri bulunurken, Rusya'nın elinde 2.398 subay (12'si imam, 90'1 doktor) ile 45.287 er olmak üzere toplam 47.867 esir bulunmaktayd. Bu durumda Almanların teklifine göre Osmanlı Devleti’nin Rusya'ya yüklü miktarda bir

90 BOA, HR.SYS, D:2240, G:4

91 BOA, HR.SYS, D:2245, G:36

92 BOA, HR.SYS, D:2239, G:3

93 Arslan, a.g.t, s.173-178

94 Arslan, a.g.t, s. 183-187 
tazminat ödemesi gerekiyordu ${ }^{95}$. Fakat bu teklif Rusya tarafından kabul edilmeyecek ve müzakereler tatil edilecektir ${ }^{96}$.

Yusuf Akçura ise Rus Harbiye-i Umumiyesi'nin esir cetvellerine dayanarak hazırlamış olduğu raporunda 1918 yılı Nisan ayı itibariyle 1.457 subay ile 17.715 er olmak üzere toplam 19.172 Türk askerinin esir olduğunu belirtmektedir. Ancak bu listenin tamam olmadığını ve sivil esir sayısını belirtmenin katiyen kabil olmadığını belirtmektedir. Akçura, tahmini bir sayı vermekte ve Rusya' da bulunan esir sayısını; 20-30 bin kuzey ve güney Kafkasya'da, 20-30 bin Rusya'nın diğer bölgelerinde olmak üzere toplam 40-60 bin arası esir olduğunu belirtmektedir $^{97}$. Bu ifadesini Türkiye'ye döndükten sonrada Türk Dünyası Gazetesi’nde yazdığı bir makalede de tekrar etmiştir. Türkiye'ye döndükten sonra 2 Teşrin-i evvel 1919 tarihli Türk Dünyası Gazetesi'nde yazdığı bir makalede ise Akçura, Rusya'da kalan esir sayısını takriben şu şekilde vermektedir ${ }^{98}$.

\begin{tabular}{|l|r|}
\hline Sovyetler Cumhuriyeti arazisinde & 400 \\
\hline Sibirya'da & 6.000 \\
\hline $\begin{array}{l}\text { Şimal-i Kafkasya ve Don Kazakları } \\
\text { ülkesinde }\end{array}$ & 2.000 \\
\hline Ukrayna'da & 800 \\
\hline Türkistan'da & 300 \\
\hline TOPLAM & 9.500 \\
\hline
\end{tabular}

Buradaki tabloya bakıldığında esirlerin bir kısmının iade edildiği rakamlardan anlaşılmakta ancak büyük bir çoğunluğun daha Rusya' da kaldığı görülmektedir.

Osmanlı Devleti, esirlerin değişimi için 20 Ekim 1917'de "Mübadele-i Üsera Komisyonu" adı altında bir komisyon kurmuştur. Komisyon, kısa bir süre sonra İsviçre'nin Bern şehrinde hasta ve malul esirlerin karşılıklı değişimi için İngiliz temsilcileriyle ${ }^{99}$, bir. araya gelerek 28 Aralık 1917 'de Bern Antlaşmasını imzalamıştır. Íngiltere'nin tespitine göre Anadolu'da bulunan esirlerden 300 İngiliz ile 700 Hintliye karşılık 1.500 Türk esiri mübadeleden faydalanacaktı. İlaveten yaşları 17 ile 50 arasındaki sivil esirler de isterlerse değişime tabi tutulabilecekti. Daha sonra Fransa'da bu heyete iștirak etmiştir. Takas yeri olarak da Kuşadası limanı kabul edilmiştir. İskenderiye'den hareket eden gemi, Kuşadası'na ulaştığında limana gelen esirler, gemiye bindirilerek önce Yunanistan'a oradan da İngiltere'ye götürülecekti ${ }^{100}$. Dahiliye Nezaretine gönderilen 19 A ğustos 1918

95 BOA, HR.HMŞ.IŞO, D:68, G:1; Kutlu, a.g.t, s.12; Arslan, a.g.t, s.192-193

96 BOA, HR.HMŞ.IŞO, D:68, G:3

97 Akçura, ...Rapor, s.90-91

98 Yusuf Akçura, “Rusya’daki Esirlerimiz Hakkında”, Türk Dünyası, 2 Teşrin-i evvel 1919, Sayı:36, s.1

99 İsviçre'nin ev sahipliğinde gerçekleșen konferansta Osmanlı Devleti'ni Albay Ziya, Muhtar ve Aziz Beyler temsil ederken İngilizleri Lord Newton ve Sir H.Beltied temsil etmiştir. Bilgi için bak. Akkor, ...Kocaeli'de Ingiliz Esirleri, s.863

100 BOA, HR.SYS D:2242 G:4; Akkor, ...Ingiliz Esirleri ve Esir Kamplarl, s.241 vd.; Özçelik, a.g.t, s.179. Daha Bern Antlaşması imzalanmadan önce Osmanlı Devleti, İngilizlerin esir değişimi teklifine sayılarına bakılmaksızın subay ve askerlerin değişiminin kabul edildiğini belirtmiştir. Bilgi için bak. BOA, HR.SYS D:2201 G:5 
tarihli bir belgede ise İngiltere'den iade edilecek Osmanlı esirlerinin memleketin emniyeti noktasından Kuşadası'na değil Beyrut'a getirilmelerinin kararlaştırıldığı ancak daha sonra Mersin'e getirilmeleri için gerekli önlemlerin alınálığı, İngiliz esirlerin de Mersin Limanı ve Kuşadası vasitasıyla gönderilecekleri belirtilmiştir ${ }^{101}$. Daha sonra bu antlaşmaya ek olarak 1918 Nisanında yedi maddelik bir ek sözleşme imzalanmıştır ${ }^{102}$.

İngiltere ve Fransa hükümetleriyle esir mübadelesine dair yapılan anlaşmaya göre esirlerin yol masraflarının tarafsız ülke sınırına kadar esir bulundukları devlet tarafından karşılanacağ ${ }^{103}$ belirtilmesine rağmen esirlerin iade masraflarını da Osmanlı Devleti kabul etmiştir. Hariciye Nezareti'ne yazılan 20 Ekim 1334 (20 Ekim 1918) tarihli bir belgede Fransa'dan deniz yoluyla iade edilecek Osmanlı esirlerinin masraflarının tarafımızdan karşılanacağı açıkça belirtilmiştir ${ }^{104}$.

\section{Esirlerin İadesi}

Osmanlı Devleti, 1918 yılının sonlarına doğru savaşı sürdüremeyeceğini anlayınca Ekim ayından itibaren mütareke yapma yollarını aramaya başlamıştır. Talat Paşa ve halefi Ahmet İzzet Paşa bu hususta yoğun girişimlerde bulunmuşlardır. Uzun uğraşlardan sonra, İtilaf Devletleri adına İngiliz Amirali Calthorpe ile Osmanlı Hükümeti adına Bahriye Nazırı Rauf Bey'in başkanlıklarını yaptıkları Türk ve İngiliz heyetleri 27 Ekim'de Mondros'ta müzakere masasına oturacaklardır. Müzakereler İngiliz Savaş Ofisi (War Office) tarafından hazırlanan mütareke taslağında yer alan hükümler dahilinde gerçekleştirilmiştir. Amiral Calthorpe'un öncelikli görevi taslağı herhangi bir değișikliğe meydan vermeden Türk tarafina kabul ettirmektir. Taslakta yer alan maddeler iki taraf arasında savaş haline son verecek şekilde hazırlanmış gibi gözükse de, esasında Osmanlı toprakları üzerinde İngiliz nüfuzunu kurmayı ve gizli anlaşmalar doğrultusunda Osmanlı topraklarının paylaşımına imkân verecek şekilde kaleme alınmıştır ${ }^{105}$.

Mondros Ateşkes Antlaşması 30 Ekim 1918 tarihinde imzalanacaktır. 24 madde halinde imzalanan Mütareke'nin iki maddesi doğrudan esirlerle alakalıdır. Bunlardan 4. madde "Itilaf Devletleri'nin bütün esirleri ile Ermeni esirleri kayltsı şartsız İstanbul'da teslim olunacaktır" derken, 22. madde "Osmanlı harp esirleri, İtilaf Devletleri nezdinde kalacaktır" demektedir. 22. maddeye ek olarak düşülen açıklamada "Sivil savaş esirleri ile askerlik yaşları dışında olanların bırakılması göz önünde bulundurulacaktır”. ş̧eklinde ifade edilmektedir. Mütareke hükümlerinden anlaşılacağı üzere artık Osmanlı Devleti, elinde bulunan esirlerin bir kısmını değil tamamını koşulsuz şartsız serbest bırakmak zorunda kalmaktadır. Buna mukabil, Osmanlı Devleti'ne ait esirlerin ne zaman teslim edileceği hiçbir şekilde dikkate dahi alınmamıştır ${ }^{106}$.

101 BOA, DH.EUM.5.Şb, D:67, G:15. BOA, HR.SYS D:2242 G:4

102 BOA, İ.DUIT, D:35, G:8

103 BOA, DH.EUM.5.Şb, D:85, G:72

104 BOA, HR.SYS D:2242 G:3

105 Selçuk Ural, “İtilaf〉 ve Ermeni Esirlerinin İadesi Meselesi” A.Ü. Atatürk İlkeleri ve İnkllâp Tarihi Enstitüsü Atatürk Dergisi, Cilt 3, Say1 3, Erzurum 2003, s.151-152

106 Akkor, .... Ingiliz Esirleri ve Esir Kampları, s. 247 
1 Mart 1335 (1 Mart 1919) tarihli Dahiliye Nezaretinden Sadarete yazılan bir belgede İtilaf devletleri ile yapılan mütarekenamenin 4.maddesi uyarınca itilaf devletlerine ve Ermenilere ait esirlerin serbest birakılması gerekmektedir. Ancak itilaf kuvvetleri bununla kalmayıp hırsızlık, cinayet gibi adi suçlardan dolayı tutuklu ve hükümlülerin de serbest bırakılmalarını istemişlerdir. Ancak bu durumun hukuk kurallarına aykırı olduğu gibi taşrada asayişsizliğe sebep olacağ konuda gerekeni yapması istenmiştir ${ }^{107}$. Maddenin uygulamasına geçmeden önce 30 Ekim 1918 itibariyle Osmanlı Devleti'nin elinde bulunan esir miktarı 12.000 kişi civarındadır ${ }^{108}$.

Kamplardaki Ermeni esirler haricinde tutuklu olanların durumlarının görüşüldüğü 24 Aralık 1918 tarihili Meclis-i Vükela toplantısında Ermeni savaş esirlerine ilaveten sürgün edilenlerin de serbest bırakılması kararı alınacaktır. Bu kararla birlikte Mondros Mütarekesi'nin 4. maddesi doğrultusunda esir kamplarında, hapishanelerde ya da sürgün olanlar dahil istisnasız tüm İtilaf Devletleri ve Ermeni esirler serbest bırakılmıştır ${ }^{109}$. Ancak bunların dışında tutulanlarda bulunmaktadır. Adi suçlardan tutuklu bulunanlar bu hükmün dışında bırakılmıştır. Adliye Nezareti, 11 Aralık 1918 'de Sadaret'e gönderdiği tezkirede sivil mahkûmların durumuna açıklık getirilmesini isteyince aynı gün toplanan Meclis-i Vükela bazı kararlar almıştır. Alınan kararlarda adi suçlardan dolayı mahkûm olanlar mütarekenin dördüncü maddesine göre tahliye edilmeyeceklerdi. Osmanlı uyruğuna geçmek isteyen Rusya, Ukrayna ve Romanya devletleri mensupları mütarekenin imzasından önce tabii oldukları devletle ilişkilerini kestiklerinden dördüncü madde dışında bırakılmış ve Osmanlı tebaası sayılarak iadeleri gerçekleştirilmemiştir ${ }^{110}$.

Esirlerin serbest bırakılmasının diğer bir sebebi de büyük çaptaki harcamalardan kurtulma isteğidir. Mondros Mütarekesi'nin imzasından 14 Şubat 1921 tarihine kadar geçen sürede Ingiltere tarafından iade edilen Türk esirlerinin sayısı 7.626 subay ve 102.950 asker olmak üzere toplam $110.576^{\prime} \mathrm{d} \mathrm{r}^{111}$.

Türk kuvvetleri, Sakarya Meydan Savaşında Yunan ordularını kesin olarak durdurunca Fransızlarla 1 Ekim 1921 tarihinde esir alınma zamanı ve mevkisi dikkate alınmadan, tüm esirlerin karşılıklı olarak değiştirilmesi kararlaştırılmıştır. İtalya ve Romanya'da bulunan Türk esirlerinin ne zaman ve hangi koşullarda yurda döndükleri bilinmemektedir. Kamplardan kaçanlar ve vefat edenler haricinde 20.000'den fazla esir 1920 yilına kadar yurda dönmüștür ${ }^{112}$.

Rusya'ya esir düssen Türk askerlerinin durumu ise önce Osmanlı Hükümeti, sonra TBMM ve akabinde de Ankara Hükümeti tarafindan takip edilmiştir. 28 Mart 1921'de Ankara ile Moskova arasında "Esir Mübadelesi Sözleşmesi" imzalanmış ve bu doğrultuda peyderpey esirler Anadolu'ya getirilmeye başlanmıştır. Ankara Hükümeti, Moskova Büyükelçiliği ve Azerbaycan dâhil diğer Sovyet Cumhuriyetlerindeki konsolosluklar

\footnotetext{
107 BOA, DH.MB.HPS D:79 G:39; BOA, BEO, D:4552, G:341369

108 Ural, a.g.m, s.153-154

109 Akkor, ...Ingiliz Esirleri ve Esir Kamplarl, s.250

110 Ural, a.g.m, s. 155

111 Akkor, ...Türk Esir Kamplart, s.198-199

112 Akkor, ...Türk Esir Kamplarl, s.200-202
} 
vasıtası ile bu coğrafyalarda kalmış Türk savaş ve sivil esirler ile savaş sırasında muhacir olarak Anadolu dışına çıkmak mecburiyetinde kalmış olan vatandaşlarını Türkiye'ye getirmek için yoğun bir çaba sarf etmiştir. Bu çếçevede 22 Şubat 1926'da 750 Numaralı Kanun kabul edilmiş ; "Türkiye ile Rusya'da dağınık bir halde kalmış harp esirlerinin... elçiler ve şehbenderler vasıtası ile" yurda getirilmesi için çalışmalar yapılmıştır. Sovyet Rusya coğrafyasında kalmış esirlerin yurda getirilmesi amacıyla Türkiye'den 11.850 Lira para gönderilmiş ve net bir sayı olmamakla beraber birçok vatandaşın Türkiye'ye dönmesi sağlanmıştır ${ }^{113}$.

Ilginç olan bir durum ise bazl sivil esirlerin Osmanl Devleti'nden gitmek istememesidir. Bern Antlaşmasi'nın imzalanmasından sonra İngiltere'de bulunan sivil Türk esirleri ile Osmanlı topraklarında bulụnan sivil İngiliz esirlerin değiştirilmesi kararı alınacaktır. Karar gereği sivil esirler, vatandaşı oldukları ülkelere gönderilecektir. Ancak ticari nedenlerle ülkesi dışında yaşayanlardan bazılarının gitmek istememesi üzerine antlaşmanın sivil esirlerle ilgili bölümüne: "17 ile 50 yaş arasindaki sivil esirler isterlerse değişime tabi tutulabilecektir" şeklinde bir düzenleme yapılmıştır. Bu durumu dikkate alan Osmanlı yetkilileri, gitmek istemeyen ya da bir müddet daha kalmak isteyen sivil esirlerin özgürce dolaşabilmelerine imkân sağlayan bir kanun çıkaracaktır ${ }^{114}$. Bir başka husus ise bazı Müslüman esirlerin Osmanlı tabiiyetine geçmek istemesidir. Örneğin Almanya'nın Ruslardan almış oldukları esirler içinde yer alan Müslüman esirler Türkiye'ye gönderilmiş ve İzmit esir kampına yerleştirilmişlerdir. Bunlardan Osmanlı vatandaşlığına geçmek isteyen Rus ve Ukraynalı Müslümanların başvuruları kabul edilmiş ve esir statüsünden kurtulmaları sağlanmıştır ${ }^{115}$.

\section{Sonuç}

Osmanlı Devleti, daha savaşın başlarından itibaren esirlerle ilgili çalışmalara başlamış, bir taraftan esirlere yapılacak muameleleri belirlemek amacıyla "Üsera Hakkında Talimatname"yi yayınlarken diğer taraftan esirlere ait işlemlerin savaş hukuku çerçevesinde düzenli ve sorunsuz yürütülebilmesi için üsera komisyonları kurmuştur. İtilaf devletleri ise Türk savaş esirlerine karşı savaş hukukuna aykırı tutum ve uygulamalar yapmışlardır. Türk esirler, gerek kamplara götürülürken, gerekse kamplarda insanlık dıșı muamelelere maruz kalmışlardır. Bununla beraber Osmanlı Devleti'nin esirlere her türlü kolaylığ gösterdiği ancak İtilaf devletlerinin aynı itinayı göstermedikleri görülmektedir. Harp esirleri tarafından gönderilen mektuplar, havaleler, posta paketleri her türlü ücretten muaf tutulmuş, esirlere ait hediye ve yardım olarak gönderilen eşyalardan gümrük vergisi alınmamış, Osmanlı Hükümeti'nce işletilen yollarda esirlerden yol ücreti talep edilmemiştir. Asayiş tedbirlerine uygun olmak şartıyla esirlerin din ve mezhebine ait mabetlere gitmelerine, dini ayinlerini yapmalarına izin verilmiştir. Esirlerin yiyeceklerini kendi mezheplerinin icaplarına göre seçmelerine ve pişirmelerine de müsaade edilmiştir. Diğer taraftan esirler,

\footnotetext{
113 Nuri Köstüklü, “Atatürk Dönemi Türkiye- Azerbaycan İlişkilerinde "Mülteciler", "Muhâcirler" ve "Esirler" Konusunda Baz1 Tespitler", Tarih Incelemeleri Dergisi C.XXXII, S.1, 2017, s.115 vd.

114 Akkor, ....ingiliz Esirleri ve Esir Kampları, s.252

115 Arslan, a.g.t, s.217-218
} 
ihtiyaçlarını karşılamak amacıyla uluslar arası hukuk kuralları çerçevesinde değişik işlerde çalıştırılmışlardır. Osmanlı Devleti'nde esirlere genelde kolaylıklar sağlanmakla beraber bazı konularda sınırlamalar getirildiği de görülmektedir. Casusluk ihtimaline karşı mektup veya kartlar Dersaadet Sansür Müfettişliği tarafından incelenmiş, sakıncalı görülenlere el konulmuştur. Esirlerin firar etmelerini önlemek amacıyla çeşitli tedbirler alınmıștır. Esirlerin sahil ve şimendifer hattından uzak mahallerde ikamet ettirilmeleri için vilayetlere uyarılarda bulunulmuş, fotoğraflarının çekilerek kaçmaları engellenmeye çalışılmış, aileleri ve yardım kuruluşları tarafından gönderilen kolilerde esirlerin firar etmesini kolaylaştıracak eşyaların olmaması için koliler sıkı bir şekilde kontrol edilmiş, hatta gönderilen paralar esirlere ihtiyaçları kadar verilmiştir. Esirlere belli saatlerden sonra dışarı çıkmalarına izin verilmediği gibi birden fazla elbise verilmemiş ve yerli ahali ile aynı elbiseleri giymeleri yasaklanmıştır. Genel olarak Osmanlı sınırları dâhilindeki esirlerin bazı küçük problemler yaşamalarına rağmen yaşamlarından memnun oldukları görülmektedir. Bu memnuniyet Salib-i Ahmer Cemiyeti’nin raporlarına da yansımıştır.

Birinci Dünya Savaşı’nın esirlerle ilgili önemli meselelerinden birisi de esir sayılarıdır. Çalışmamızda da görüleceği üzere, sayılarla ilgili net bir rakam vermek dönemin koşulları gereği mümkün görünmemektedir. Zira esir kayıtları düzenli tutulmadığı gibi esirlerden ne kadarının savaş esiri, ne kadarının sivil esir statüsünde olduğunu tespit etmek mümkün değildir. Örneğin bizzat konu ile ilgilenmesine rağmen Akçura, esir sayılarını verirken tahmini rakamlar vermekte, kesin bir say verememektedir. Benzer durumlar Rus esir kayıtlarında da gözlemlenmektedir. Rus kayıtlarına bakıldığında kayıtların birbirleriyle örtüşmediği açıkça görülmektedir. Bir başka husus ise İtilaf devletlerinin esir değişimi konusunda eşitlik ilkesine aykırı davranmasıdır. Zira Mondros mütarekesi bunun açık bir delilidir.

Esirlerle ilgili iş ve işlemler genellikle Hollanda, ABD, İspanya gibi tarafsız devletler aracılığıyla yürütülmeye çalışılmıştır. Her ne kadar savaş süresince esir değişimleri söz konusu olsa da genellikle göze çarpan husus, esir değişimlerinde eşitlik ilkesine riayet edilmemesi ve esirlere insani olmayan muamelelerde bulunulmasidır.

\section{KAYNAKÇA}

A- Osmanlı Arşivi Daire Başkanlığı (BOA) (Birinci sayı dosya numarası, ikinci sayı gömlek numarasıdır)

1- Bab-1 Ali Evrak Odası (BEO)

$4552 / 341369$

2- Dâhiliye Nezareti Emniyet-i Umumiye Müdüriyeti, 5.Şube (DH.EUM.5.Şb)
$4 / 36$
$15 / 57$
$61 / 2$
$67 / 15$
$85 / 72$

3- Dahiliye Nezareti Mebani-i Emiriye Hapishaneler Müdüriyeti (DH.MB.HPS) 
$79 / 39$

4- Hariciye Nezareti, Hukuk Müşavirliği, İstişare Odası (HR.HMŞ.IŞO)

$43 / 2268 / 1 \quad 68 / 3$

5- Hariciye Nezareti, Siyasi Kısım (HR.SYS)

$2189 / 12189 / 2 \quad 2201 / 5 \quad 2206 / 6 \quad 2213 / 1$

$2213 / 32240 / 4 \quad 2242 / 2 \quad 2242 / 3 \quad 2242 / 4$

$2245 / 36 \quad 2247 / 37 \quad 2247 / 43 \quad 2411 / 34 \quad 2239 / 3$

$2240 / 12247 / 6 \quad 2978 / 27$

6- Hariciye Nezareti Sofya Sefareti (HR.SFR.04)

$491 / 26$

7- İradeler, Dosya Usulü (I.DUİT)

$35 / 8$

8- İradeler, Mabeyn-i Hümayun (İ.MBH)

$16 / 106$

\section{B-RESMI YAYINLAR}

Osmanlı Belgelerinde Birinci Dünya Harbi C.1, Başbakanlık Devlet Arşivleri Genel Müdürlüğ̈̈ Osmanlı Arşivi Daire Başkanlı̆̆ı Yayınları, Yayın Nu: 130, İstanbul 2013

\section{C-KITAP, MAKALE ve BILDIRILER}

AKÇURA, Yusuf, Rusya Üsera Murahhassı Yusuf Akçura Bey’in Raporu, Matbaa-i Orhaniye, Dersaadet 1335

AKKOR, Mahmut, "I.Dünya Savaşı'nda Kocaeli'de İngiliz Esirleri”, Uluslar arası Gazi Akça Koca ve Kocaeli Tarihi Sempozyumu, 2-4 Mayıs 2014, ss.849-867

ARIKAN, Mustafa, "Birinci Cihan Harbi Türk Esir Mektuplarında Duygu ve Düşünceler”, Osmanlı Araştırmaları Dergisi XI, İstanbul 1991, ss.35-48 
ASKER, Ali, "Birinci Dünya Savaşı'nda Rusya'daki Türk Esirleri Konusunda Bazı Tespitler", 1914'ten 2014'e 100'üncü Yilında Birinci Dünya Savaşı'nt Anlamak Uluslararası Sempozyumu, 20-21 Kasim 2014, İstanbul, ss.543-576

ÇAPA, Mesut, "Birinci Dünya Savaşında Türkiye'de İtilaf Devletleri Askerleri", Toplumsal Tarih Dergisi, Haziran 1999, ss.49-56

GAFAROV, Vasif, "Birinci Dünya Savaşı Yıllarında Rus Esirlerin Tutuldukları Osmanlı Kampları Ve Yozgat Üsera Garnizonu' I. Uluslararası Bozok Sempozyumu Bildiri Kitabı C.2, 5-7 May1s 2016, ss.122-131

KÖSTÜKLÜ, Nuri, “I. Dünya Savaşında Rusya'nın Ukrayna ve Diğer Bölgelerindeki Türk Savaş Esirlerine Dair Bazı Tespitler", Atatürk Araştırma Merkezi Dergisi C.XXVIII, S.83, Ankara, Temmuz 2012, ss.1-16

, "Birinci Dünya Savaşında Polonya'da Şehit Olan Türkler ve Türkiye'de Ölen Polonyali Askerler", Türkiye Polonya İlişkilerinde Temas Alanları (1414-2014) Uluslararası Konferansı, Bildiriler Kitabı, Türk Tarih Kurumu yay., Ankara 2017, ss.323355

, "Atatürk Dönemi Türkiye- Azerbaycan İlişkilerinde "Mülteciler", "Muhâcirler" ve "Esirler" Konusunda Bazı Tespitler", Tarih Incelemeleri Dergisi C.XXXII, S.1, 2017, ss.109-124

METiN, Celal, "Yusuf Akçura ve I.Dünya Savaşı'nda Rusya'daki Türk Esirleri", Modern Türklük Araştırmaları Dergisi, C.2, S.3, Ankara 2005, ss.31-53

SONAT, Ramazan, "I.Dünya Savaşı Yıllarında Osmanlı Devletinin Muhasım Devlet Tebaası Politikası (1914 $\square 1918)$ ", Tarihin Peşinde Dergisi, Y11, 2014, S.11, ss.259-290

TEMEL, Mehmet, "Birinci Dünya Savaşı Yıllarında 1907 Tarihli Lahey Sözleşmelerine Aykırı Davranan İtilaf Devletlerine Karşı Osmanlı Devleti'nin Aldığı Bazı Önlemler", Balıkesir Üniversitesi Sosyal Bilimler Enstitüsü Dergisi, C.6, S.10, Balıkesir 2003, ss.147167

UCA, Alaattin, "1915 Yılında Yayımlanan Bir Üsera Talimatnamesi ve Düşündürdükleri”, A.Ü. Atatürk İlkeleri ve İnkılâp Tarihi Enstitüsü Atatürk Dergisi, Cilt 3, Say1 3, Erzurum 2003, ss.169-183

URAL, Selçuk, "İtilafł ve Ermeni Esirlerinin İadesi Meselesi" A.Ü. Atatürk İlkeleri ve İnkılâp Tarihi Enstitüsü Atatürk Dergisi, Cilt 3, Say1 3, Erzurum 2003, ss.151-167

\section{GAZETELER}

AKÇURA, Yusuf, "Rusya'daki Esirlerimiz Hakkında”, Türk Dünyası, 2 Teşrin-i 
evvel 1919, Say1:36, s.1

IKDAM, “Cihad-ı Ekber”, 13 Kasim 1914,NNumru: 6369, s.1

SABAH, “Beyanname-i Hümayun Suretidir”, 13 Kasım 1914, Numru: 9036, s.1

TANIN, "Beyanname-i Hümayun Suretidir", 13 Teşrin-i sani 1914, Numru: 2117, s.1

\section{TEZLER}

AKKOR, Mahmut, I. Dünya Savaşi'nda Anadolu'daki İngiliz Esirleri ve Esir Kampları, Sakarya Üniversitesi Sosyal Bilimler Enstitüsü (Yayınlanmamış Doktora Tezi), Sakarya 2013

, I. Dünya Savaşında Çeșitli Ülkelerdeki Türk Esir Kampları, Sakarya Üniversitesi Sosyal Bilimler Enstitüsü (Yayınlanmamış Yüksek Lisans Tezi), Sakarya 2006

ARSLAN, Nebahat Oran, I.Dünya Savaşı'nda Türkiye'deki Rus Savaş Esirleri ve Bunların İadeleri, Atatürk Üniversitesi Sosyal Bilimler Enstitüsü (Yayınlanmamış Doktora Tezi), Erzurum 2003

KUTLU, Cemil, I.Dünya Savaşı'nda Rusya'daki Türk Savaş Esirleri ve Bunların Yurda Döndürülme Faaliyetleri, Atatürk Üniversitesi Atatürk İlkeleri ve İnk1lâp Tarihi Enstitüsü (Yayınlanmamış Doktora Tezi), Erzurum 1997

ÖZÇELIK, Mücahit, Birinci Dünya Savaşı'nda Türkiye'deki Yabancı Esirler, Gazi Üniversitesi Sosyal Bilimler Enstitüsü (Yayınlanmamış Doktora Tezi), Ankara 2010

\section{INTERNET SITELERI}

http://www.zafersen.com/birinci-dunya-savasinda-osmanli-esirleri-ve-dramlari.pdf (Erişim tarihi 04.01.2018)

https://tr.wikipedia.org/wiki/Kostroma (Erişim tarihi 04.01.2018) 